\title{
A Mechanistic Study of the Electron Capture Dissociation of Oligonucleotides
}

\author{
Tak Wah Dominic Chan, Man Fai Choy, Wai Yi Kelly Chan, \\ and Yi Man Eva Fung \\ Department of Chemistry, The Chinese University of Hong Kong, Hong Kong, China
}

\begin{abstract}
Electron capture dissociation (ECD) of a series of custom-synthesized oligonucleotide pentamers was performed in a Fourier-transform mass spectrometer with a conventional filamenttype electron gun. Dissociation of oligonucleotide ions by electron capture generates primarily $w / d$-type and $z / a$-type ions with and without the loss of a nucleobase fragment ions. Minor yields of radical $[\mathrm{z} / \mathrm{a}+\mathrm{H}]$. fragment ions were also observed in many cases. It is interesting to note that some nucleoside-like fragment ions and protonated nucleobase ions (except thymine-related nucleobases and nucleoside-like fragments) were observed in most ECD spectra. The formation of these low-mass fragment ions was tentatively attributed to the secondary fragmentation of the radical $[z+H]$. fragment ions. From the ECD tandem mass spectra of a series of C/T based binary oligonucleotide ions, including $\mathrm{d}(\mathrm{CTCTC}), \mathrm{d}(\mathrm{CTTTC})$, $\mathrm{d}(\mathrm{TCCCT}), \mathrm{d}(\mathrm{CCCCT})$, and $\mathrm{d}(\mathrm{TCCCC})$, it was clearly demonstrated that the formation of many sequence ions was sensitive to the position of cytosine (or the position of charge carrier). The findings of this work support a notion that the ECD of protonated oligonucleotide molecules is charge-directed with the electron being captured by the protonated nucleobase. (J Am Soc Mass Spectrom 2009, 20, 213-226) (c) 2009 Published by Elsevier Inc. on behalf of American Society for Mass Spectrometry
\end{abstract}

S tructural characterization of deoxyribonucleic acid (DNA) and ribonucleic acid (RNA) is important, as DNA and RNA play important roles in many biochemical processes. Even with the completion of the human genome project, the importance of studying nucleic acid remains. For instance, a large region of DNA requires re-sequencing [1] to allow the detection and characterization of nucleotide mutation. There is a constant demand for powerful and rapid analytical methods to determine the structure of nucleic acids and their constituents. With the development of "soft" desorption/ionization techniques, matrix-assisted laser desorption/ionization (MALDI) [2, 3] and electrospray ionization (ESI) [4, 5] methods, mass spectrometry has become an indispensable, quick, and reliable tool for the analysis of oligonucleotides [6]. However, simple mass measurement provides little structural information for confirmation of the sequence for unknown natural and synthetic oligonucleotides. Much research effort has recently been devoted to the development of various tandem mass spectrometry (MS/MS) methods for structural elucidation of biomolecules. The critical event in tandem mass spectrometry of biomolecules is the activation of the selected precursor ions to induce unimolecular dissociation. Common ion activation methods used for analysis of biomolecules include low-

Address reprint requests to Dr. T. W. Dominic Chan, Department of Chemistry, The Chinese University of Hong Kong, Shatin, N.T., Hong Kong SAR, China. E-mail: twdchan@cuhk.edu.hk and high-energy collision-induced dissociation (CID) $[7,8]$, surface-induced dissociation (SID) [9], infrared multiphoton dissociation (IRMPD) [10], and blackbody infrared radiative dissociation (BIRD) [11]. However, fragment ions observed in the tandem mass spectra using these ion activation methods mostly originate from cleavages of weak bonds [12].

A relatively new ion activation method, electron capture dissociation (ECD) [13] has demonstrated several interesting features. For example, for protein-type biomolecules, ECD leads predominantly to the dissociation of the $\mathrm{N}-\mathrm{C}_{\alpha}$ linkage even in the presence of labile post-translational modifications [14, 15]. A combination of ECD and other dissociation methods, such as IRMPD and CID, has been shown to provide complementary information for unambiguous identification of the type and the position of several important protein posttranslational modifications [16-18] and for de novo sequencing [19]. Although the use of the ECD method for tandem mass spectrometry analysis of peptides/ proteins has become increasingly popular [20-22], the mechanism of the peptides/proteins dissociation remains unclear [23]. The prevailing mechanistic models are the so-called "hot hydrogen atom" and "superbase" models. The "hot hydrogen atom" model involves the capture of the electron at the charged site [13]. Ionelectron recombination at a protonated amine leads to the formation of a hypervalent species [13], and then the transfer of a hot hydrogen atom to the backbone carbonyl group to form the labile ketylamino radical. 
Decomposition of the ketylamino radical leads to the formation of $c$ - and $z$. fragment ions. The "superbase" model postulates that the presence of a remote charge substantially increases the electron affinity of the backbone carbonyl groups [24]. Direct capture of the electron by a backbone carbonyl group leads to the formation a localized anionic radical. Theoretically, this anionic radical is even more basic than arginine and is capable of abstracting a proton from vicinity to form the labile ketylamino radical [24]. Similarly, decomposition of the ketylamino radical leads to the formation of $c$ - and $z$. fragment ions. Much less is known for the dissociation mechanism of DNA fragments under ECD conditions. Håkansson and coworkers have studied several synthetic DNA oligomers using the ECD method [25]. Base loss and sequence specific fragments, such as $\mathrm{w}^{+}$and $\mathrm{z}^{+}$, were found to be the dominant fragment species. Through the ECD studies of a number of small oligonucleotides, they proposed a dissociation mechanism to account for the observed fragmentation pattern. This mechanism resembles the "superbase" model and involves the capture of the electron by the neutral phosphate backbone to form an anionic phosphate radical. Decomposition of this radical leads to the characteristic $\mathrm{w}_{n}$ and $\mathrm{d}_{n}$ fragment ions.

In a more recent work, Hakansson and co-workers found that the ECD fragmentation patterns of the oligonucleotides are nucleobase dependent and proposed that cleavage might induced by electron capture at the nucleobase [26].

Through the use of a series of custom-synthesized oligonucleotides with predefined sequences of nucleotides, this paper aims to provide more spectral information and hopefully a better understanding of ECD mechanism of oligonucleotides. The experimental work divides into two major parts. First, four pentameric oligonucleotides with a general sequence of CCXXC, where $\mathrm{X}$ corresponds to the four different nucleotides, i.e., C, A, G, and T, were examined under ECD conditions. This set of experiments aims to provide general information on the types and relative abundances of common fragmentation products. The use of asymmetric sequences was to avoid mass redundancy and to differentiate $\mathrm{w}_{n} / \mathrm{d}_{n}$ and $\mathrm{a}_{n} / \mathrm{z}_{n}$ fragment ions. Second, the ECD spectra of a series of $\mathrm{C} / \mathrm{T}$ binary-based pentameric oligonucleotides were obtained under ECD conditions. These oligonucleotides include $\mathrm{d}(\mathrm{CTCTC})$, d(TCCCT), d(CTTTC), d(CCCCT), and (TCCCC). This set of experiments was designed to examine the correlation between the protonation site and the cleavage pattern of the oligonucleotides. Under the present experimental conditions, it was believed and confirmed that protonation was restricted to the cytosine bases, and thymine bases were free from protonation. This is consistent with their large difference in relative proton affinities [27]. The main goal of this investigation was to prove whether electron capture at the protonated site is the initiating step for ECD fragmentation of positive oligonucleotide ions.

\section{Experimental}

\section{Materials}

All materials were obtained commercially and were used without further purification. HPLC grade methanol was purchased form (Dublin, Ireland). Formic acid $(98.7 \%)$ and ammonium fluoride (98\%) were purchased from Sigma Chemical, St. Louis, MO. $\mathrm{d}$ (CCCCC), d(CCAAC), d(CCTTC), and d(CCGGC) oligonucleotides were purchased from (Lewisville, TX) as their crude ammonium salts, and were used without further purification. $d($ CTCTC), d(CTTTC), d(TCCCT), $d(T C C C C)$, and $d(C C C C T)$ were synthesized in-house as their crude ammonium salts.

\section{Sample Preparation}

The lyophilized samples were dissolved in deionized water $(18 \mathrm{M} \Omega)$ to a concentration of $1 \times 10^{-3} \mathrm{M}$. Before nanospray ionization, the stock solutions were further diluted using a mixture of methanol and $\mathrm{H}_{2} \mathrm{O}$ (1:1 vol:vol) with $1 \%$ formic acid to a concentration of $2.5 \times$ $10^{-4} \mathrm{M}$. All sample solutions were freshly prepared before mass spectrometry analysis to avoid alkali-ions contamination.

\section{Instrumentation}

All experiments were performed by using a 4.7 Tesla FTMS system (Bruker Instrument Inc., Boston, MA) equipped with an unshielded 4.7 Tesla superconducting magnet and a homemade nanospray ion source. Details of the homemade nanospray ion source have been reported previously [28]. (The original APEX I console was upgraded to APEX III). Typically, $10 \mu \mathrm{L}$ of the sample solution was loaded into a tapered nanospray tip by using a $10 \mu \mathrm{L}$ syringe and was grounded with a $15 \mu \mathrm{m}$ tungsten wire. The nanospray tip was positioned to 1 to $2 \mathrm{~mm}$ in front of a dielectric capillary. Spraying of the sample solution was induced by floating the front metal cap of the dielectric capillary to -900 to $-1100 \mathrm{~V}$. A steam of heated dry nitrogen gas $\left(\sim 200^{\circ} \mathrm{C}\right)$ was used to warm up the dielectric capillary and to assist the desolvation of the analyte ions from the sprayed droplets. The sprayed position was adjusted by using a $x-y-z$ manipulator and was monitored by CCD cameras. Ions formed were temporarily accumulated in a hexapole ion guide for 2 to $4 \mathrm{~s}$ before being transferred into the infinity cell [29]. Ion transmission from the external source into the trapped cell was achieved by using the standard electrostatic lens system. The sidekick ion accumulation method was used to facilitate the ion trapping process. In all experiments, static trapping potentials of $1.0 \mathrm{~V}$ were used.

For the ECD experiments, the standard electrically- 
heated filament source was used to produce a pulse of electron beam. The filament was made of rhenium ribbon and was fixed at a distance of $108 \mathrm{~mm}$ from the rear end of the infinity cell. Details of the geometry of the filament source have been described previously [30]. Typical experimental conditions were $3.3 \mathrm{~A}$ filament current, $4.5 \mathrm{~V}$ average filament bias voltage and $500 \mathrm{~ms}$ electron irradiation time. To avoid timeconsuming pump delay, no pulse gas was used in the present experiment. All ECD mass spectra were acquired in broadband mode using a 128 kbyte dataset. One hundred scans were summed to improve the signal-to-noise ratio. The time-domain signals were zero-filled once before Fourier transformation.

\section{Method of Calculations}

Standard ab initio calculations were performed by using Gaussian 03 molecular orbital packages [31]. All the molecular geometries, including neutral and anionic radical $\left(\mathrm{CH}_{3}\right)_{2} \mathrm{PO}_{4} \mathrm{H}$, neutral, protonated and neutral radical methylated nucleic bases. $m C, m A, m G$, and $m T$ represent the neutral methylated-cytosine, methylated adenine, methylated guanine and methylated thymine, respectively. Their structures were optimized with density functional theory calculation using Becke's hybrid functional (B3LYP) [32-34] and the 6-31+G(d,p) basis set. The optimized structures were characterized by harmonic frequency analysis as local minima (all frequencies real). The B3LYP frequencies were corrected by 0.9806 and were used to calculate zero-point vibrational corrections. Single-point energies were calculated at B3LYP level using $6-31+G(3 d f, 2 p)$ basis set. Spin contamination in calculations with unrestricted wave functions was found to be negligible to moderate. The $\left\langle\mathrm{S}^{2}\right\rangle$ operator expectation values were $0.75-0.77$ for UB3LYP calculations of local minima. The calculated total energies, uncorrected harmonic frequencies and complete geometries (Cartesian atomic coordinates) are given.

\section{Results and Discussion}

\section{$E C D$ of $d(C C C C C), d(C C A A C), d(C C T T C)$, and $d(C C G G C)$}

General features. Figure 1 shows ECD mass spectra of doubly-protonated molecules of (a) d(CCCCC), (b) $\mathrm{d}($ CCAAC), (c) d(CCTTC), and (d) d(CCGGC). The spectral information was summarized in Table 1. Dissociation of oligonucleotides by electron capture generates primarily even-electron $w / d$-type sequence ions, i.e., $w_{4}^{+} / d_{4}^{+}$fragment ions for $\mathrm{d}(\mathrm{CCCCC}), \mathrm{d}(\mathrm{CCAAC})$ and $\mathrm{d}(\mathrm{CCTTC}) ; w_{3}^{+} / d_{3}^{+}$fragment ions for $\mathrm{d}(\mathrm{CCCCC})$; and $w_{3}^{+}$fragment ion for $\mathrm{d}(\mathrm{CCAAC}), \mathrm{d}(\mathrm{CCTTC})$, and $\mathrm{d}(\mathrm{CCGGC})$, respectively [25]. Except the spectrum of
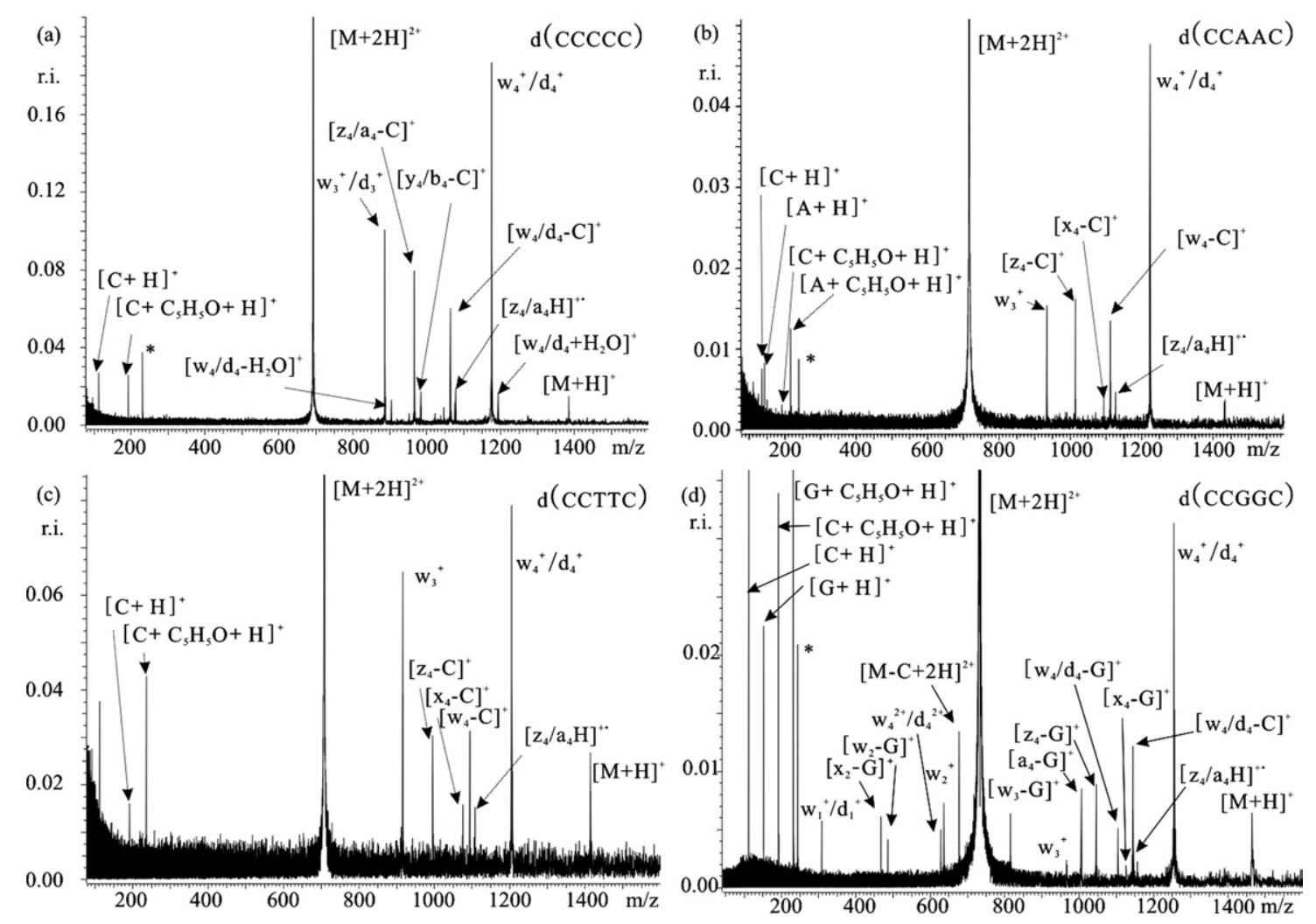

Figure 1. Typical electron capture dissociation mass spectra of isolated doubly-protonated oligonucleotide molecules of (a) d(CCCCC); (b) d(CCAAC); (c) d(CCTTC); and (d) d(CCGGC) (100 summed scan, 500 ms electron irradiation). Peaks marked with an asterisk are electronic noises. 


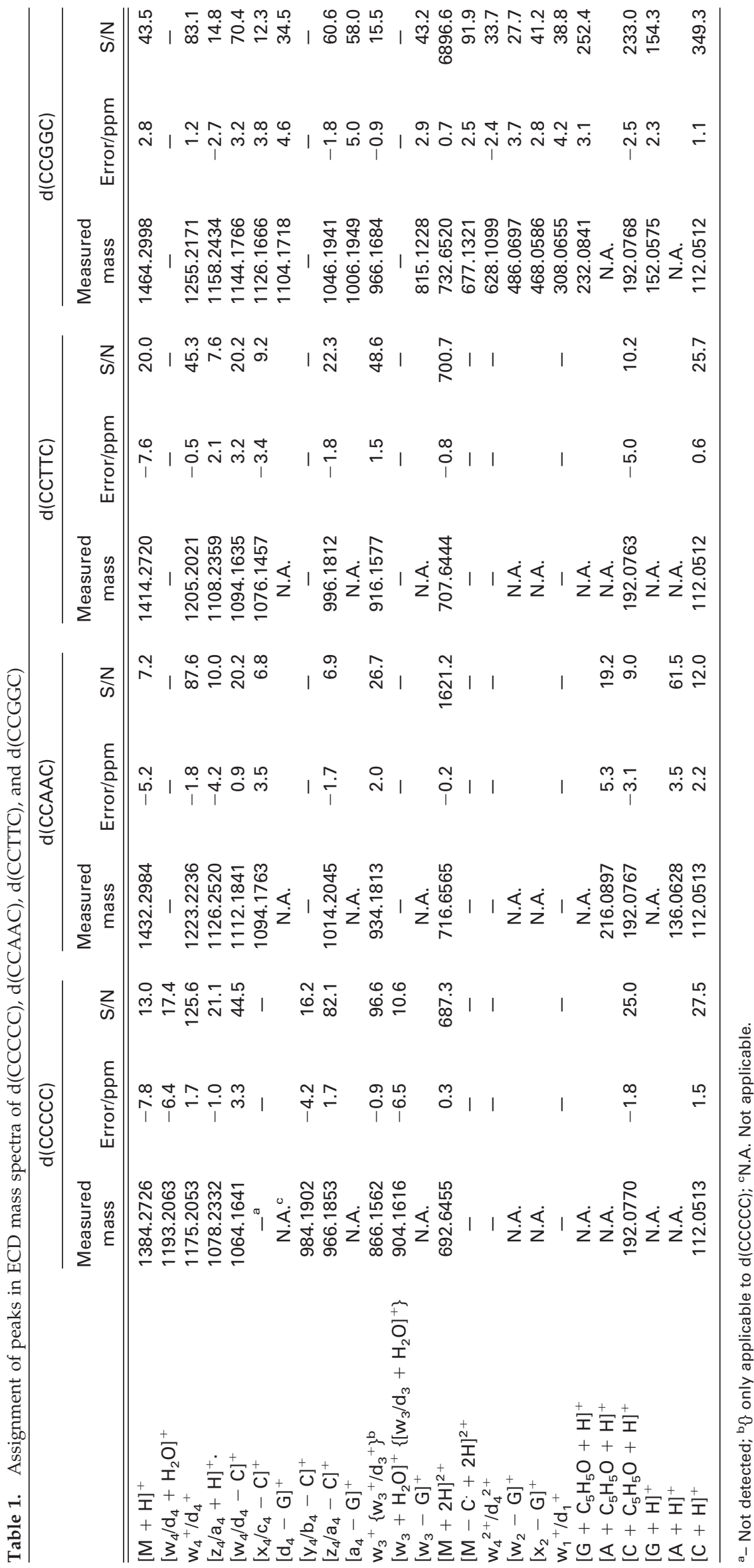


d(CCGGC), none of the ECD spectra obtained in this study generated enough fragment ions for complete mapping of the oligonucleotide sequence. Due presumably to the lability of the protonated cytosine, these ECD spectra have strong fragment ions corresponding to the loss of a cytosine base from $w / d-, z / a-$, and $x / c$-type fragment ions. For d(CCGGC), fragment ions corresponding to the loss of a guanine base from $d$ - and $a$-type fragment ions were also observed. Some $[z+$ $\mathrm{H}] \cdot /[\mathrm{a}+\mathrm{H}] \cdot-$ type radical ions were observed as minor fragment ions in these ECD mass spectra.

Protonated nucleobases and nucleoside-like fragments. Inspecting the low-mass regions of Figure $1 \mathrm{a}-\mathrm{d}$, it is interesting to find that signals corresponding to the protonated bases and nucleoside-like fragment ions were also observed. These low-mass fragment ions have not previously been reported $[25,26]$. For d(CCCCC), the observed low-mass fragment ion corresponds to the protonated base fragment ions $\mathrm{CH}^{+}$, where $\mathrm{C}$ represents a neutral cytosine base. The other low-mass ion at $m / z 192$ was assigned as $\left[\mathrm{C}+\mathrm{C}_{5} \mathrm{H}_{5} \mathrm{O}+\mathrm{H}\right]^{+}$. This nucleoside-like fragment ion has previously been observed in the CID mass spectra of oligonucleotides [35]. Similar low-mass fragment ions were also observed in $\mathrm{d}(\mathrm{CCAAC})$ and $\mathrm{d}$ (CCTTC). For d(CCAAC), the low-mass fragment ions include protonated base, $\mathrm{CH}^{+}$and $\mathrm{AH}^{+}$; and nucleosidelike fragment ions, $\left[\mathrm{C}+\mathrm{C}_{5} \mathrm{H}_{5} \mathrm{O}+\mathrm{H}\right]^{+}$and $\left[\mathrm{A}+\mathrm{C}_{5} \mathrm{H}_{5} \mathrm{O}+\right.$ $\mathrm{H}^{+}$. For $\mathrm{d}(\mathrm{CCTTC})$, only protonated cytosine $\left(\mathrm{CH}^{+}\right)$ and the corresponding nucleoside-like fragment ion, $\left[\mathrm{C}+\mathrm{C}_{5} \mathrm{H}_{5} \mathrm{O}+\mathrm{H}\right]^{+}$were observed. Protonated thymine base $\left(\mathrm{TH}^{+}\right)$and the corresponding nucleoside-like frag- ment ion, $\left[\mathrm{T}+\mathrm{C}_{5} \mathrm{H}_{5} \mathrm{O}+\mathrm{H}\right]^{+}$were not observed (see Figure 1c).

The formation of internal nucleoside-like fragment ions, such as $\left[\mathrm{A}+\mathrm{C}_{5} \mathrm{H}_{5} \mathrm{O}+\mathrm{H}\right]^{+}$from $\mathrm{d}(\mathrm{CCAAC})$, is intriguing and is fundamentally important. From the ECD experiment of a doubly-protonated oligonucleotide species, this type of internal nucleoside-like fragment ions were generated from capture of one electron and cleavage of two separate backbone linkages. Intuitively, this internal fragment ion could be formed from secondary dissociation of the ECD-induced primary fragment ions due presumably to the excess internal energy deposition during the ion-electron recombination process. Because of the absence of larger internal fragments, this secondary dissociation should not be formed from even-electron fragments and should be formed by radical initiated reactions. This type of secondary dissociation has previously been observed in hot-ECD of peptides/proteins in which the labile $\mathrm{z}^{+}$. could undergo side-chain loss reactions [36]. Scheme 1 shows plausible mechanisms for the formation of the protonated nucleobase fragment ions and nucleosidelike fragment ions. In the proposed schemes, the $[\mathrm{z}+$ $\mathrm{H}]^{+}$. was attributed to be the key intermediate for the formation of these fragment species. In line with the abundance of $\mathrm{z}^{+}$. species in ECD of peptides/proteins [37], $[\mathrm{z}+\mathrm{H}]^{+}$. species in ECD spectra of oligonucleotides were usually of low abundance with respect to other even-electron fragment ions, such as $\mathrm{w}_{n}^{+} / \mathrm{d}_{n}^{+}$. From Scheme 1, $\left[\mathrm{z}_{n}+\mathrm{H}\right]^{+}$. species could undergo two competitive reactions leading to the formation of $[\mathrm{B}+$ $\mathrm{H}^{+}$and $\left[\mathrm{z}_{n}-\mathrm{B}\right] \cdot\left(\right.$ or $[\mathrm{B}]$ and $\left.\left[\mathrm{z}_{n}-\mathrm{B}+\mathrm{H}\right]^{+} \cdot\right)$; and $\left[\mathrm{z}_{(n-1)}\right] \cdot$,

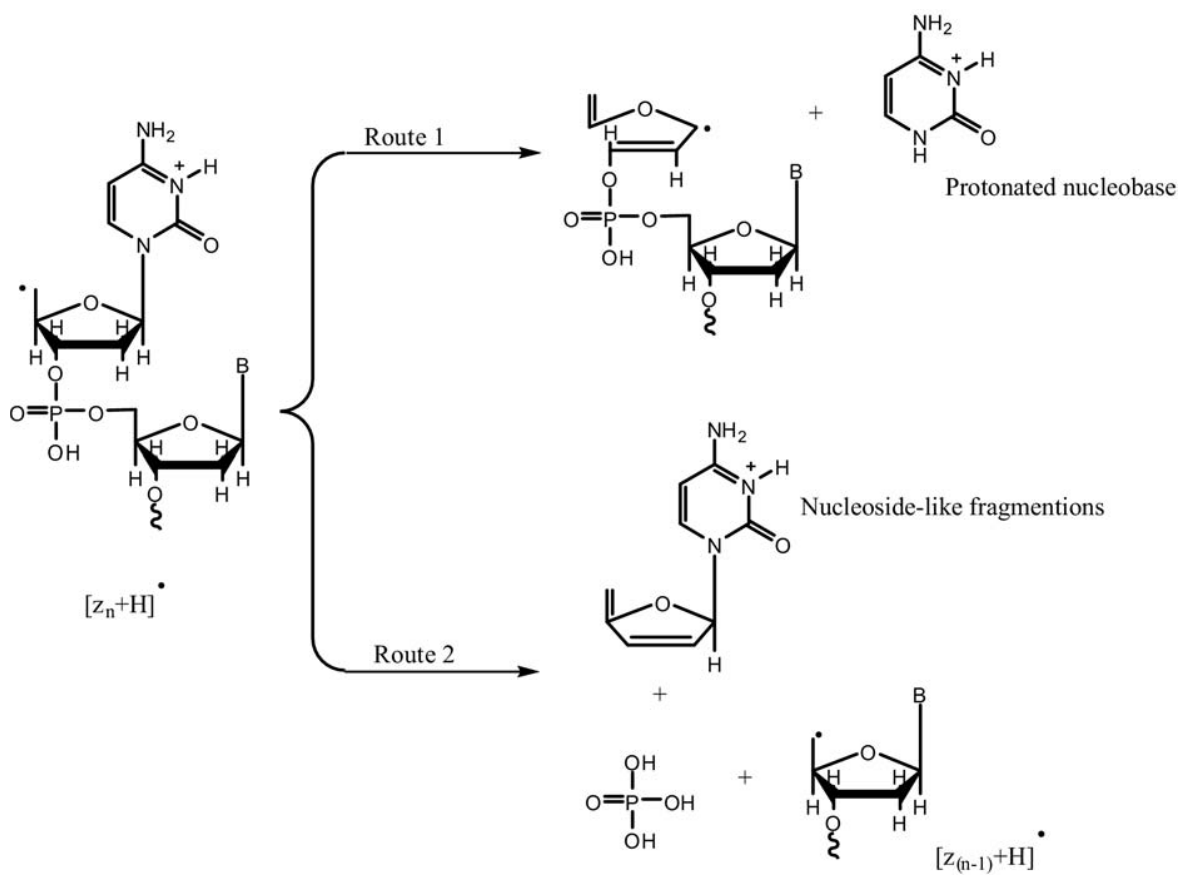

Scheme 1. Proposed mechanisms for secondary dissociation of the radical $z$-ion to generate protonated nucleobase and nucleoside-like fragment ions. 
$\mathrm{H}_{3} \mathrm{PO}_{4}$ and nucleoside-like fragment ions (or $\left[\mathrm{z}_{(n-1)}+\right.$ $\mathrm{H}]^{+} \cdot, \mathrm{H}_{3} \mathrm{PO}_{4}$ and nucleoside-like neutral fragment). The former dissociation pathway involves 1,2-elimination reaction, whereas the latter dissociation pathway involves the elimination of a neutral phosphate moiety and the formation of another $\left[\mathrm{z}_{(n-1)}+\mathrm{H}\right]^{+}$. species. To observe the nucleoside-like fragment ions and protonated nucleobase, the nucleobase must have sufficient high proton affinity. The absence of $\left[\mathrm{T}+\mathrm{C}_{5} \mathrm{H}_{5} \mathrm{O}+\mathrm{H}\right]^{+}$ and $\mathrm{TH}^{+}$in ECD of $\mathrm{d}(\mathrm{CCTTC})$ is consistent with the relatively low proton affinity of thymine base.

Doubly-charged fragments ions. Figure $1 \mathrm{~d}$ shows a typical ECD mass spectrum of doubly-protonated d(CCGGC). Compared with mass spectra of oligonucleotides without guanine base (i.e., $\mathrm{d}(\mathrm{CCCCC}), \mathrm{d}($ CCAAC), and $\mathrm{d}(\mathrm{CCTTC})$ ), the mass spectrum of $\mathrm{d}($ CCGGC) displays many common fragment ions, including $w_{4}^{+},\left[\mathrm{w}_{4}-\right.$ $\mathrm{C}^{+},\left[\mathrm{z}_{4}-\mathrm{C}\right]^{+}$, protonated bases fragment ions $\left(\mathrm{CH}^{+}\right.$ and $\mathrm{GH}^{+}$) and nucleoside-like fragment ions ([C + $\left.\mathrm{C}_{5} \mathrm{H}_{5} \mathrm{O}+\mathrm{H}\right]^{+}$and $\left[\mathrm{G}+\mathrm{C}_{5} \mathrm{H}_{5} \mathrm{O}+\mathrm{H}^{+}\right)$. However, this spectrum also displays some doubly charged fragment ions, such as $\mathrm{w}_{4}^{2+}$ and $[\mathrm{M}-\mathrm{C}+2 \mathrm{H}]^{2+}$. The formation of doubly-charged fragment ions from the electron capture dissociation mass spectrum of a doubly-protonated oligonucleotide species is intriguing. Such doublycharged fragment ions have also been reported in literature [25]. The possibility of generating these fragment ions from metastable decay of the doublycharged precursor ions was eliminated by performing an additional control experiment. This control experiment was conducted right after the acquisition of the normal ECD spectrum of $d(C C G G C)$ using the same tuning conditions and pulse program except the electron irradiation event. The electron irradiation event was replaced by a delay of the same duration. To eliminate the possible complication of blackbody radiation irradiative dissociation, the electron gun (i.e., the filament) was kept at high temperature in both actual and control experiments. The control experiment verified that these doubly-charged fragment ions were indeed generated by the electron irradiation event. Håkansson et al. attributed the formation of these doubly charged fragment ions to the zwitterionic nature of the precursor ions [25]. The authors postulated that the gas-phase doubly-charged precursor ions might adopt a configuration that has at least three protonated nucleobases and one deprotonated phosphate group. If one protonated nucleobase is neutralized by the incoming electron, the cleavage product ions can still be a doubly-protonated species so long as the other dissociation product can carry the deprotonated phosphate group. At first glance, this proposal seems logical. However, close inspection of the model reveals some problems. Under this model, if one fragment is positively charged with two protons, the other fragment must be negatively charged with a deprotonated functional group. Splitting of these oppositely charged fragments is energetically unfavorable process. In addition, this model cannot possibly be used to account for the formation of $w_{4}^{2+}$ fragment ion as found in the present study. For a pentameric oligonucleotide precursor ion, $w_{4}^{2+}$ fragment ion carries all the backbone phosphates. It implies that the other departing fragment could not contain any deprotonated functional groups. A plausible explanation for the formation of these doublycharged fragment ions involves the electronic excitation dissociation (EED) process. In a typical EED process, the precursor ions are electronically excited by some highenergy electrons $(\geq 20 \mathrm{eV})$ to a repulsive state that leads to unimolecular dissociation of the precursor ions. No change in the charge-state of the precursor ions is involved in the whole process. Therefore, singlycharged precursor ions can give singly-charged fragment ions; and doubly-charged precursor ions can give doubly-charged fragment ions. This process has also previously been used to explain the metastable dissociation of precursor ions formed by MALDI method [38]. Although the average energy of the electrons used in the present ECD experiment was only $4.5 \mathrm{eV}$, the actual energy distribution of the electron beam could be quite broad. It was quite feasible that these doubly charged fragment ions were induced by high-energy portion of the electron beam. In addition, the reference value of $\sim 20 \mathrm{eV}$ for EED process was derived from experiments using peptide ions. The on-set conditions for EED of doubly-charged oligonucleotide ions might be substantially milder than that of singly-charged peptide ions.

\section{Theoretical Calculation of Electron Capture Affinities of Common Functionalities in Oligonucleotides}

To investigate the dissociation mechanisms of oligonucleotide ions under ECD conditions, it is necessary to have some information regarding the capture site of the incoming electron. In this section, the electron affinities of common functionalities of oligonucleotides were computed using DFT calculations. Scheme 2 shows the structures of the models used to compute the electron affinities. These models include four different protonated methylated nucleobases, dimethylated phosphate and protonated deoxyribose monophosphate $5^{\prime} \mathrm{dCMP}$ and $3^{\prime} \mathrm{dCMP}$. The protonated sites of the methylated nucleobases were assigned based on the literature reports [39-40]. Briefly, these include $\mathrm{N}_{1}$ of adenine, $\mathrm{N}_{7}$ of guanine, $\mathrm{N}_{3}$ of cytosine and $\mathrm{O}_{4}$ of thymine. Using the present level of computation, the proton affinities of these methylated nucleobases are $-233.0 \mathrm{kcal} / \mathrm{mol}$, $-231.0 \mathrm{kcal} / \mathrm{mol},-227.9 \mathrm{kcal} / \mathrm{mol}$, and $-208.9 \mathrm{kcal} /$ $\mathrm{mol}$ for $\mathrm{mG}, \mathrm{mC}, \mathrm{mA}$, and $\mathrm{mT}$, respectively. Table 2 summarizes the computed electron affinities. It is found that the electron capture reaction of protonated methylated nucleobases are quite exothermic (ranging from -102 to $-124 \mathrm{kcal} / \mathrm{mol}$ ); whereas the electron capture reaction of dimethylated phosphate is highly endothermic $(+314 \mathrm{kcal} / \mathrm{mol})$. Using protonated 


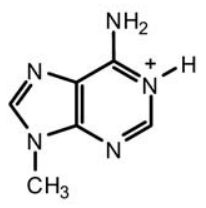

(a)

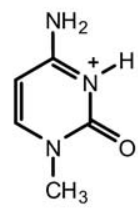

(b)

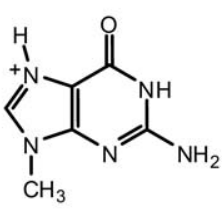

(c)<smiles>Cc1cn(C)c(=O)[nH]c1=[OH+]</smiles>

(d)

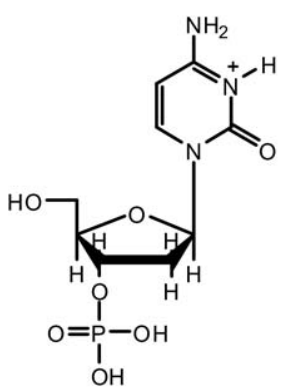

(e)

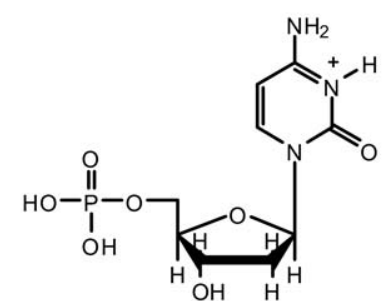

(f)

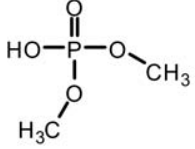

(g)

Scheme 2. Truncated DNA model structures used to compute the ion-electron recombination energies for the protonated adenine (a), cytosine (b), guanine (c), thymine (d), deoxycytidine$3^{\prime}$ monophosphate (e), deoxycytidine-5'monophosphate (f), and the electron affinity of the neutral phosphate $(\mathrm{g})$.

$5^{\prime}$-deoxycytidine monophosphate $\left(5^{\prime} \mathrm{dCMP}\right)$ and protonated $3^{\prime}$-deoxycytidine monophosphate ( $\left.3^{\prime} \mathrm{dCMP}\right)$ models, the electron capture reaction of the $5^{\prime} \mathrm{dCMP}$ was found to be roughly $10 \mathrm{kcal} / \mathrm{mol}$ more exothermic than that of the $3^{\prime} \mathrm{dCMP}$. There are several limitations associated with these calculations. These calculations were performed using simple truncated functionalities of the oligonucleotides. The effect of remote charges, electronic effect of the sugar ring and the influence of the intramolecular interactions of the "real" oligonucleotide ions were not considered. The former is particularly important as a recent report has shown that remote charges can substantially increase the electron affinity of carbonyl group in peptides [24]. Nevertheless, the results of these simple calculations imply that electron capture at the protonated nucleobases should be energetically more favorably than the neutral phosphodiester groups.

Table 2. A summary of the computational ion-electron recombination energies and electron affinity for various truncated DNA models. Structures were computed at B3LYP / 6-31+G(p,d)//B3LYP 6-31+G(3df, 2p), including zero-point energy corrections at B3LYP $/ 6-31+(\mathrm{d}, \mathrm{p})$

\begin{tabular}{lc}
\hline \multicolumn{1}{c}{ Reaction } & Reaction energy $^{a}$ \\
\hline \hline$[\mathrm{mA}+\mathrm{H}]^{+}+\mathrm{e}^{-} \rightarrow[\mathrm{mA}+\mathrm{H}] \cdot$ & -102.077 \\
{$\left[\mathrm{mC}+\mathrm{H}^{+}+\mathrm{e}^{-} \rightarrow[\mathrm{mC}+\mathrm{H}] \cdot\right.$} & -117.341 \\
{$[\mathrm{mG}+\mathrm{H}]^{+}+\mathrm{e}^{-} \rightarrow[\mathrm{mG}+\mathrm{H}] \cdot$} & -102.702 \\
{$[\mathrm{mT}+\mathrm{H}]^{+}+\mathrm{e}^{-} \rightarrow[\mathrm{mT}+\mathrm{H}] \cdot$} & -124.736 \\
$\left(\mathrm{CH}_{3}\right)_{2} \mathrm{PO}_{4} \mathrm{H}+\mathrm{e}^{-} \rightarrow\left[\left(\mathrm{CH}_{3}\right)_{2} \mathrm{PO}_{4} \mathrm{H}\right] \cdot \cdot^{-}$ & 314.392 \\
{$\left[5^{\prime}-\mathrm{dCMP}+\mathrm{H}\right]^{+}+\mathrm{e}^{-} \rightarrow\left[5^{\prime}-\mathrm{dCMP}+\mathrm{H}\right] \cdot$} & -115.984 \\
{$\left[3^{\prime}-\mathrm{dCMP}+\mathrm{H}\right]^{+}+\mathrm{e}^{-} \rightarrow\left[3^{\prime}-\mathrm{dCMP}+\mathrm{H}\right]$.} & -106.622
\end{tabular}

aln units of $\mathrm{kcal} / \mathrm{mol}$ at $0 \mathrm{~K}$.

\section{Electron Capture Dissociation of C/T Binary-Based Oligonucleotides}

To consolidate this electron capture model, a series of custom-synthesized $\mathrm{C} / \mathrm{T}$ binary-base oligonucleotides were examined under ECD conditions. From the proton affinity values of the methylated nucleobases (see Table $2)$, it was postulated that protonation at cytosine should be energetically more favorable than that of thymine. This postulation is consistent with the literature findings [25] that doubly-protonated $d\left(G_{5}\right)$, $d\left(C_{5}\right)$, and $d\left(A_{5}\right)$ could be generated at ease and doubly-protonated $d\left(T_{5}\right)$ could hardly be formed under typical electrospray ionization conditions. As a consequence, the charging positions of an oligonucleotide could be controlled by varying the number and position of the $C$ and $T$ nucleotides within the $C / T$ binary-base oligonucleotide ions; and the importance of the protonated nucleobases on the electron capture event could be studied.

$E C D$ of $d(C T C T C), d(T C C C T)$, and $d(C T T T C)$. Figure $2 \mathrm{a}-\mathrm{c}$ show typical ECD mass spectra of doubly-protonated $\mathrm{d}($ CTCTC), d(TCCCT), and d(CTTTC), respectively. The spectral information was extracted and was summarized in Table 3. Because of the symmetry of these oligonucleotides, many of the characteristic fragment ions are isomeric in natures and have exactly the same $\mathrm{m} / \mathrm{z}$ values. Typical isomeric fragment ions include $w_{n}$ and $d_{n}$ ions; $x_{n}$ and $c_{n}$ ions; $y_{n}$ and $b_{n}$ ions; and $z_{n}$ and $a_{n}$ ions. Based on simple mass measurements, these ions could not be differentiated and were labeled with a "slash". ECD spectra of these oligonucleotide ions show series of fragment ions corresponding to $w / d$-type, $z / a$ - 


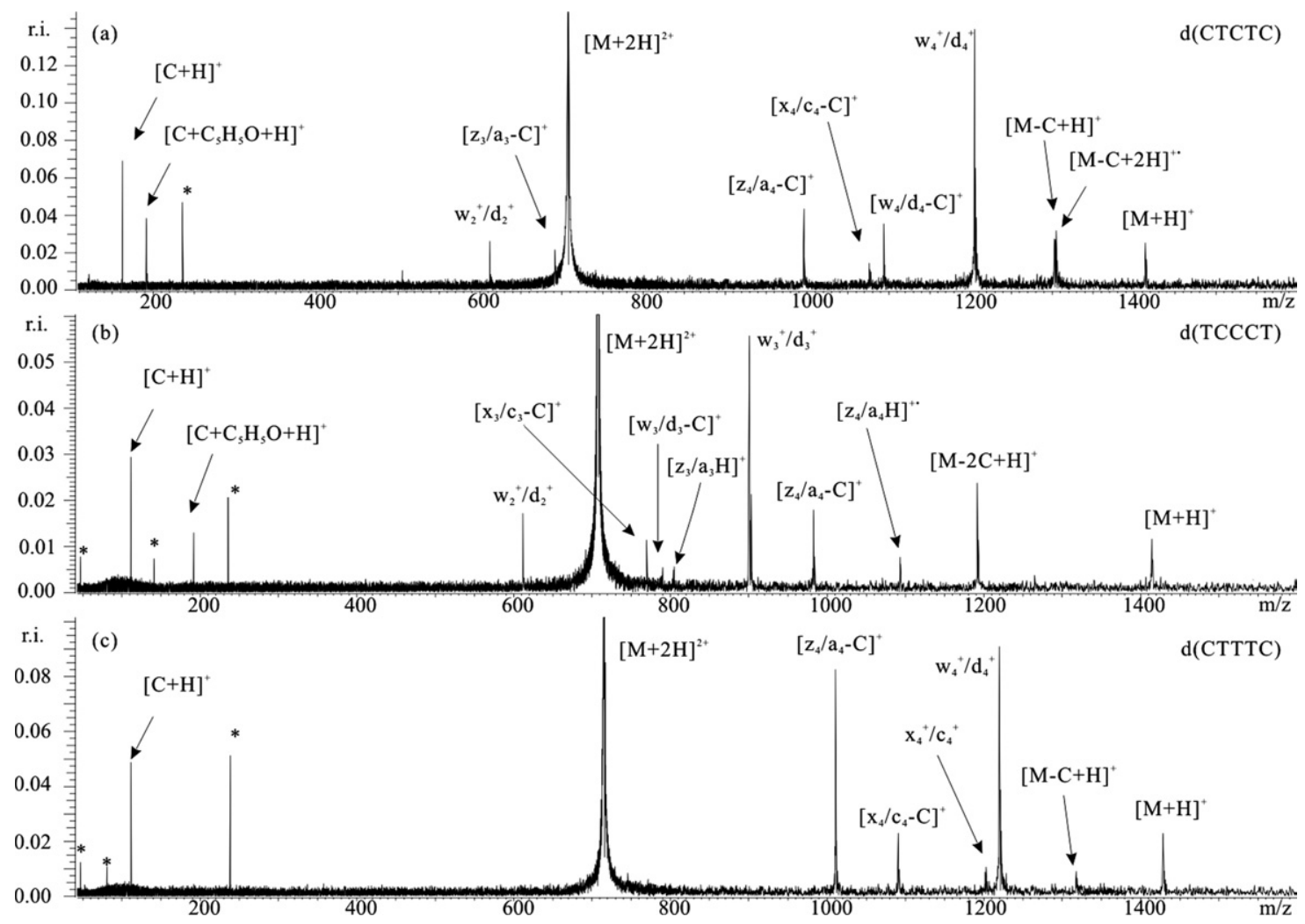

Figure 2. Typical electron capture dissociation mass spectra of isolated doubly-protonated oligonucleotide molecules of (a) d(CTCTC); (b) d(TCCCT); and (c) d(CTTTC) (100 summed scan, $500 \mathrm{~ms}$ electron irradiation). Peaks marked with an asterisk are electronic noises.

type, and $x / c$-type. The reduced precursor ions and some of fragment ions were found to undergo additional loss of one (or two) cytosine moiety. For the ECD mass spectra of $\mathrm{d}(\mathrm{CTCTC})$ and $\mathrm{d}(\mathrm{TCCCT})$, reasonably strong signals were found at $\mathrm{m} / \mathrm{z}^{\prime}$ s corresponding to the $\mathrm{CH}^{+}$and $\left[\mathrm{C}+\mathrm{C}_{5} \mathrm{H}_{5} \mathrm{O}+\mathrm{H}\right]^{+}$. Only $\mathrm{CH}^{+}$was however

Table 3. Assignment of peaks in ECD mass spectra of d(CTCTC), d(TCCCT), and d(CTTTC)

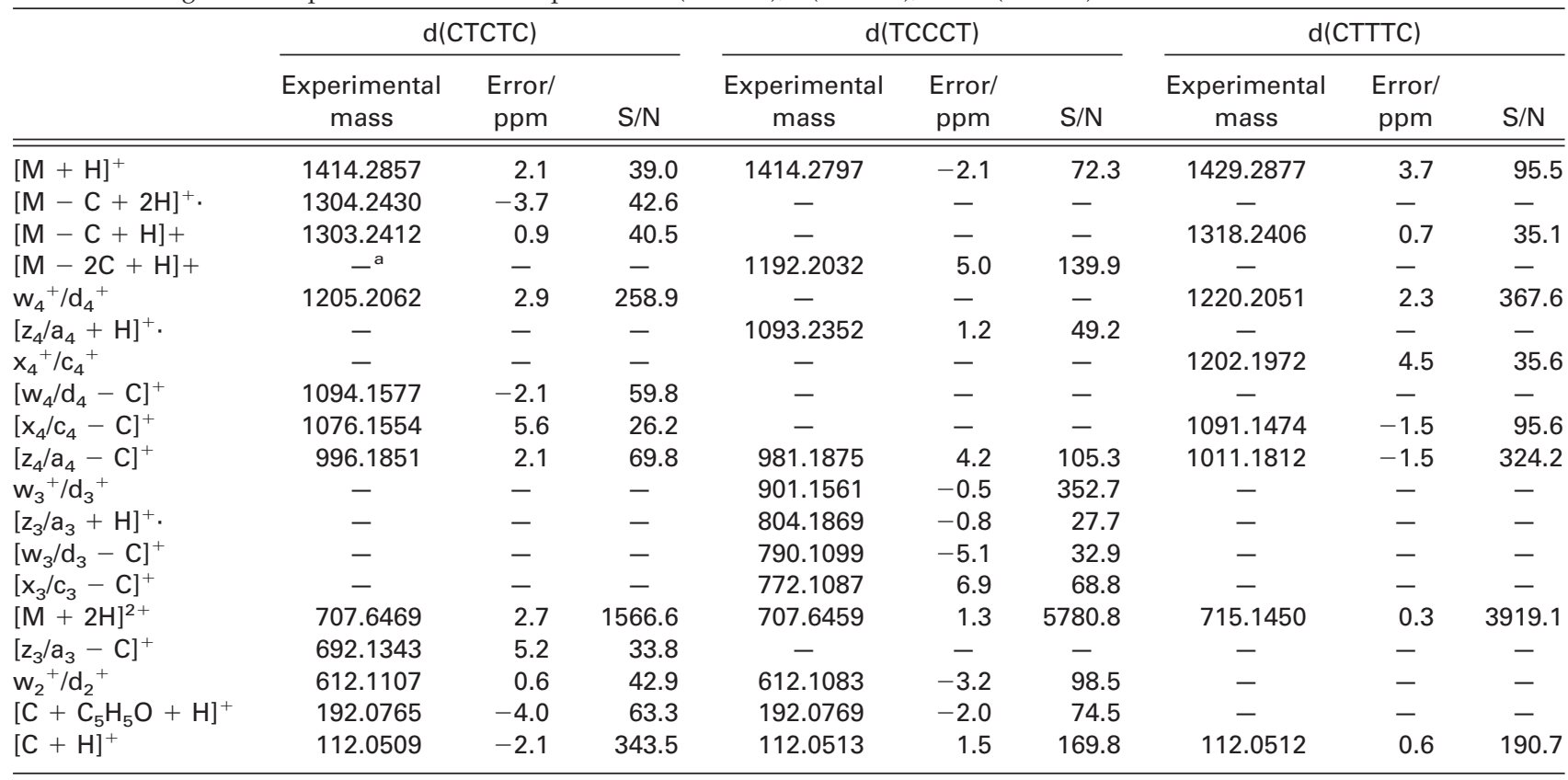

a Not detected. 
found in the ECD spectrum of d(CTTTC). Close inspection of the speciation of individual fragment ions revealed that there exists a strong correlation between the positions of the cytosine units and the presence (or absence) of certain members of $\mathrm{w}_{n} / \mathrm{d}_{n}$ fragment ions. For instance, ECD of $\mathrm{d}(\mathrm{CTCTC})$ gave $\mathrm{w}_{4}^{+} / \mathrm{d}_{4}^{+}$and $\mathrm{w}_{2}^{+} / \mathrm{d}_{2}^{+}$, but not $\mathrm{w}_{3}^{+} / \mathrm{d}_{3}^{+}$fragments; ECD of $\mathrm{d}$ (TCCCT) gave $\mathrm{w}_{3}^{+} / \mathrm{d}_{3}^{+}$ and $\mathrm{w}_{2}^{+} / \mathrm{d}_{2}^{+}$, but not $\mathrm{w}_{4}^{+} / \mathrm{d}_{4}^{+}$fragments; ECD of $\mathrm{d}$ (CTTTC) gave $\mathrm{w}_{4}^{+} / \mathrm{d}_{4}^{+}$, but neither $\mathrm{w}_{3}^{+} / \mathrm{d}_{3}^{+}$nor $\mathrm{w}_{2}^{+} / \mathrm{d}_{2}^{+}$fragments.

ECD of $d$ (CCCCT) and d(TCCCC). Figure $3 a$ and $b$ show typical ECD mass spectra of doubly-protonated $\mathrm{d}(\mathrm{CCCCT})$, and $\mathrm{d}(\mathrm{TCCCC})$, respectively. The spectral information was extracted and was summarized in Table 4 . Because of the asymmetric nature of these oligonucleotides, $w_{n}$ and $d_{n}$ ions; $x_{n}$ and $c_{n}$ ions; $y_{n}$ and $b_{n}$ ions; and $z_{\mathrm{n}}$ and $a_{n}$ ions are no long isomeric ion pairs. ECD experiments of these oligonucleotides should provide valuable information for the confirmation of the existence of $\mathrm{w}_{n}$ and/or $\mathrm{d}_{n} ;[\mathrm{z}+\mathrm{H}] \cdot$ and/or $[\mathrm{a}+\mathrm{H}]$. fragment ions. ECD mass spectra of these asymmetric oligonucleotides show series of fragment ions corresponding to $\mathrm{w}^{-}, \mathrm{d}-$, and $[\mathrm{z}+\mathrm{H}]$--type. The reduced precursor ions and some of fragment ions were found to undergo additional loss of one (or two) cytosine moiety. In both cases, reasonably strong signals were found at $m / z$ corresponding to the $\mathrm{CH}^{+}$and $\left[\mathrm{C}+\mathrm{C}_{5} \mathrm{H}_{5} \mathrm{O}+\mathrm{H}\right]^{+}$. Again, there exists a strong correlation between the positions of the cytosine units and the presence (or absence) of certain members of $w_{n} / d_{n}$ fragment ions. For ECD experiments of $\mathrm{d}(\mathrm{CCCCT}), w_{4}^{+}, w_{3}^{+}, w_{2}^{+}, d_{3}^{+}, \mathrm{d}_{2}^{+}$ and $\left[z_{4}+H\right]^{+}$. species were formed with no trace of $d_{4}^{+}$ or any members of $\left[a_{n}+H\right]^{+} \cdot$ In contrast, the ECD spectrum of $\mathrm{d}$ (TCCCC) gives $d_{4}^{+}, d_{3}^{+}, w_{3}^{+}$and $\left[z_{4}+\mathrm{H}\right]^{+}$. species but not $w_{4}^{+}$or any members of $\left[\mathrm{a}_{n}+\mathrm{H}\right]^{+} \cdot$

Based on the experimental results derived from the ECD mass spectra of these five $\mathrm{C} / \mathrm{T}$ binary oligonucleotide ions, several empirical correlations could be obtained: (1) cytosine base at (5- $n$ ) nucleotide (count from $5^{\prime}$ - to $3^{\prime}$-terminal) is essential for the formation of $w_{n}^{+}$ species; (2) cytosine base at $(n+1)$ nucleotide is essential for the formation of $\mathrm{d}_{n}^{+}$; (3) only $\left[\mathrm{z}_{n}+\mathrm{H}\right]^{+}$. were formed from ECD of oligonucleotides; (4) as reflected from the absence of $\mathrm{TH}^{+}$and $\left[\mathrm{T}+\mathrm{C}_{5} \mathrm{H}_{5} \mathrm{O}+\right.$ $\mathrm{H}^{+}$in all spectra, there is no evidence for thymine base to be protonated in these $\mathrm{C} / \mathrm{T}$ binary base oligonucleotide ions under the stated experimental conditions.

Mechanistic implications. Table 5 summarizes the spectral information related to (a) the backbone cleavages; and (b) the bass-losses from the precursor and fragment ions of the various $\mathrm{C} / \mathrm{T}$ binary base oligonucleotides under ECD conditions. Based on consistency evaluation, there seems to be strong correlation between the position of cytosine and the production of sequence specific ions. For instance, the presence of cytosine at

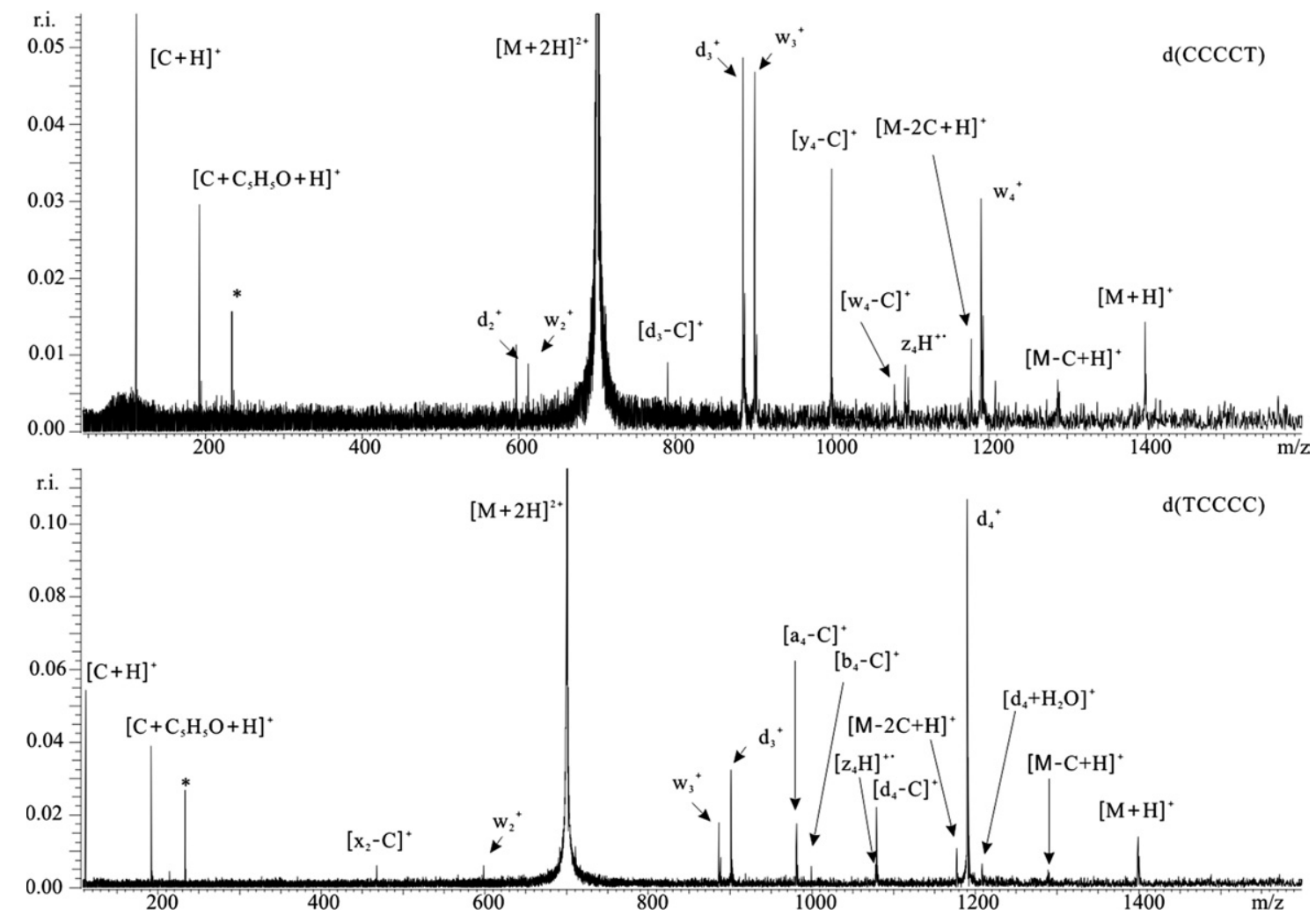

Figure 3. Typical electron capture dissociation mass spectra of isolated doubly-protonated oligonucleotide molecules of (a) d(CCCCT); and (b) d(TCCCC) (100 summed scan, $500 \mathrm{~ms}$ electron irradiation). Peaks marked with an asterisk are electronic noises. 
Table 4. Assignment of peaks in ECD mass spectra of $\mathrm{d}(\mathrm{CCCCT})$ and (TCCCC)

\begin{tabular}{|c|c|c|c|c|c|c|}
\hline & \multicolumn{3}{|c|}{$\mathrm{d}(\mathrm{CCCC})$} & \multicolumn{3}{|c|}{$\mathrm{d}(\mathrm{TCCCC})$} \\
\hline & $\begin{array}{c}\text { Experimental } \\
\text { Mass }\end{array}$ & Error/ppm & $\mathrm{S} / \mathrm{N}$ & $\begin{array}{c}\text { Experimental } \\
\text { Mass }\end{array}$ & Error/ppm & $\mathrm{S} / \mathrm{N}$ \\
\hline$[\mathrm{M}+\mathrm{H}]^{+}$ & 1399.2902 & 5.1 & 99.6 & 1399.2887 & 4.1 & 50.8 \\
\hline$[\mathrm{M}-\mathrm{C}+\mathrm{H}]^{+}$ & 1288.2455 & 4.0 & 43.7 & 1288.2465 & 4.8 & 23.0 \\
\hline $\mathrm{w}_{4}^{+}$ & 1190.2019 & -0.9 & 200.6 & - & - & - \\
\hline$\left[\mathrm{d}_{4}+\mathrm{H}_{2} \mathrm{O}\right]^{+}$ & $-^{a}$ & - & - & 1208.2159 & 1.9 & 27.7 \\
\hline $\mathrm{d}_{4}^{+}$ & - & - & - & 1190.2062 & 2.7 & 330.4 \\
\hline$[\mathrm{M}-2 \mathrm{C}+\mathrm{H}]^{+}$ & 1177.2042 & 5.6 & 79.4 & 1177.1941 & -3.0 & 40.1 \\
\hline$\left[\mathrm{z}_{4}+\mathrm{H}\right]^{+}$ & 1093.2376 & 3.4 & 59.8 & 1078.2365 & 2.1 & 18.9 \\
\hline$\left[\mathrm{w}_{4}-\mathrm{C}\right]^{+}$ & 1079.1664 & 5.7 & 40.2 & - & - & - \\
\hline$\left[\mathrm{d}_{4}-\mathrm{C}\right]^{+}$ & - & - & - & 1079.1655 & 4.8 & 71.3 \\
\hline$\left[\mathrm{y}_{4}-\mathrm{C}\right]^{+}$ & 999.1908 & -3.3 & 2240.0 & - & - & - \\
\hline$\left[b_{4}-c\right]^{+}$ & - & - & - & 999.1931 & -0.9 & 22.8 \\
\hline$\left[\mathrm{a}_{4}-\mathrm{C}\right]^{+}$ & - & - & - & 981.1867 & 3.4 & 59.2 \\
\hline$w_{3}^{+}$ & 901.1587 & 2.3 & 325.9 & 886.1574 & 0.5 & 69.3 \\
\hline $\mathrm{d}_{3}^{+}$ & 886.1566 & -0.4 & 315.3 & 901.1579 & 1.4 & 102.8 \\
\hline$\left[\mathrm{w}_{3}-\mathrm{C}\right]^{+}$ & 790.1191 & 6.5 & 58.7 & - & - & - \\
\hline$[\mathrm{M}+2 \mathrm{H}]^{2+}$ & 700.1440 & -1.8 & 6493.5 & 700.1468 & 2.3 & 3427.6 \\
\hline $\mathrm{w}_{2}^{+}$ & 612.1095 & -1.3 & 56.9 & 597.1115 & 1.5 & 17.4 \\
\hline $\mathrm{d}_{2}^{+}$ & 597.1117 & 1.9 & 73.1 & - & - & - \\
\hline$\left[\mathrm{x}_{2}-\mathrm{C}\right]+$ & - & - & - & 468.0593 & 4.2 & 18.2 \\
\hline$\left[\mathrm{C}+\mathrm{C}_{5} \mathrm{H}_{5} \mathrm{O}+\mathrm{H}\right]^{+}$ & 192.0769 & -2.1 & 191.3 & 1092.0763 & -5.0 & 128.3 \\
\hline$[\mathrm{C}+\mathrm{H}]^{+}$ & 112.0515 & 3.3 & 472.9 & 112.0510 & -1.0 & 161.8 \\
\hline
\end{tabular}

a - Not detected.

position 1 seems to be essential for the formation of $w_{4}^{+}$. Other correlation pairs include cytosine at position 2 for the formation of $w_{3}^{+}, d_{3}^{+},\left[\mathrm{z}_{3}+\mathrm{H}\right]^{+}$, and $\left[\mathrm{z}_{4}+\mathrm{H}\right]^{+}$; cytosine at position 3 for the formation of $\mathrm{w}_{2}^{+}, \mathrm{d}_{2}^{+}$, and $\left[\mathrm{z}_{3}+\mathrm{H}\right]^{+\cdot}$; cytosine at position 4 for $\mathrm{w}_{3}^{+}, \mathrm{d}_{3}^{+},\left[\mathrm{z}_{3}+\mathrm{H}\right]^{+}$, and $\left[\mathrm{z}_{4}+\mathrm{H}\right]^{+} \cdot$; and cytosine at position 5 for $\mathrm{d}_{4}^{+}$. Some correlation ambiguities could however be found using the spectral information generated from these oligonucleotides. For instance, cytosine at both position 2 and 4 could be correlated to the formation of $w_{3}^{+}, d_{3}^{+}$, and $\left[z_{3}+\right.$ $\mathrm{H}]^{+}$, and cytosine at both position 2,3 , and 4 could be correlated to the formation of $\left[\mathrm{z}_{3}+\mathrm{H}\right]^{+} \cdot$. To eliminate those ambiguous correlations, the generality of those unambiguous correlations must first be explored. For instance, the remote cytosines at position 1 and 2 were found to have no effect on the formation of $d_{4}^{+}$; and the remote cytosines at position 4 and 5 have no effect on the formation of $w_{4}^{+}$. The presence of remote cytosine at position 4 should not lead to the formation of $w_{3}^{+}$nor $\left[\mathrm{z}_{4}+\mathrm{H}\right]^{+} ;$; and the cytosine at position 2 should not lead to the formation of $\mathrm{d}_{3}^{+}$. If the formation of $\left[\mathrm{z}_{4}+\right.$ $\mathrm{H}^{+}$. was associated with the cytosine at position 2 , then

Table 5. A summary of the spectral information related to the (a) backbone cleavages; and (b) base-losses from the precursor and fragment ions of various C/T binary base oligonucleotides under ECD tandem mass spectrometry conditions

\begin{tabular}{|c|c|c|c|}
\hline \multirow[b]{2}{*}{ Oligonucleotides } & \multicolumn{2}{|r|}{ Positive identification } & \multirow[b]{2}{*}{ Negative identification } \\
\hline & Non-sequence specific ions & Sequence specific ions & \\
\hline \multicolumn{4}{|l|}{$\overline{\text { (a) }}$} \\
\hline$d(\operatorname{CccCC})$ & {$\left[\mathrm{C}+\mathrm{C}_{5} \mathrm{H}_{5} \mathrm{O}+\mathrm{H}\right]^{+}$} & $\begin{array}{l}{\left[\mathrm{w}_{4} / \mathrm{d}_{4}+\mathrm{H}_{2} \mathrm{O}\right]^{+} ;\left[\mathrm{w}_{3} / \mathrm{d}_{3}+\mathrm{H}_{2} \mathrm{O}\right]^{+} ; \mathrm{w}_{4}{ }^{+} / \mathrm{d}_{4}{ }^{+} ;} \\
\quad \mathrm{w}_{3}{ }^{+} / \mathrm{d}_{3}{ }^{+} ;\left[\mathrm{z}_{4} / \mathrm{a}_{4}+\mathrm{H}\right]^{+} .\end{array}$ & \\
\hline $\mathrm{d}(\mathrm{CTCTC})$ & {$\left[\mathrm{C}+\mathrm{C}_{5} \mathrm{H}_{5} \mathrm{O}+\mathrm{H}\right]^{+}$} & $\mathrm{w}_{4}^{+} / \mathrm{d}_{4}^{+} ; \mathrm{w}_{2}^{+} / \mathrm{d}_{2}^{+}$ & $\mathrm{w}_{3}{ }^{+} / \mathrm{d}_{3}{ }^{+}$ \\
\hline $\mathrm{d}(\mathrm{TCCCT})$ & {$\left[\mathrm{C}+\mathrm{C}_{5} \mathrm{H}_{5} \mathrm{O}+\mathrm{H}\right]^{+}$} & $\mathrm{w}_{3}^{+} / \mathrm{d}_{3}^{+} ; \mathrm{w}_{2}^{+} / \mathrm{d}_{2}^{+} ;\left[\mathrm{z}_{4} / \mathrm{a}_{4}+\mathrm{H}\right]^{+} ;\left[\mathrm{z}_{3} / \mathrm{a}_{3}+\mathrm{H}\right]^{+}$ & $\mathrm{w}_{4}^{+} / \mathrm{d}_{4}^{+}$ \\
\hline $\mathrm{d}(\mathrm{CTTTC})$ & - & $\mathrm{w}_{4}^{+} / \mathrm{d}_{4}^{+} ; \mathrm{x}_{4}^{+} / \mathrm{c}_{4}^{+}$ & $\begin{array}{l}\mathrm{w}_{3}^{+} / \mathrm{d}_{3}^{+} ; \mathrm{w}_{2}^{+} / \mathrm{d}_{2}^{+} ; \\
\quad\left[\mathrm{C}+\mathrm{C}_{5} \mathrm{H}_{5} \mathrm{O}+\mathrm{H}\right]^{+}\end{array}$ \\
\hline $\mathrm{d}(\mathrm{CCCCT})$ & {$\left[\mathrm{C}+\mathrm{C}_{5} \mathrm{H}_{5} \mathrm{O}+\mathrm{H}\right]^{+}$} & $\mathrm{w}_{4}^{+} ; \mathrm{w}_{3}^{+} ; \mathrm{w}_{2}^{+} ; \mathrm{d}_{3}^{+} ; \mathrm{d}_{2}^{+} ;\left[\mathrm{z}_{4}+\mathrm{H}\right]^{+}$ & $\mathrm{d}_{4}^{+}$ \\
\hline $\mathrm{d}(\mathrm{TCCCC})$ & {$\left[\mathrm{C}+\mathrm{C}_{5} \mathrm{H}_{5} \mathrm{O}+\mathrm{H}\right]^{+}$} & $\mathrm{w}_{3}^{+} ; \mathrm{d}_{4}^{+} ;\left[\mathrm{d}_{4}+\mathrm{H}_{2} \mathrm{O}\right]^{+} ; \mathrm{d}_{3}^{+} ;\left[\mathrm{z}_{4}+\mathrm{H}\right]^{+}$. & $\mathrm{w}_{4}^{+} ; \mathrm{w}_{2}^{+} / \mathrm{d}_{2}^{+}$ \\
\hline \multicolumn{4}{|c|}{ 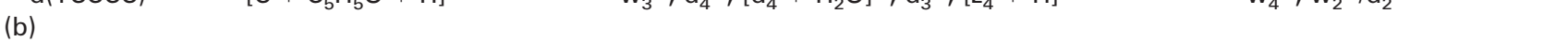 } \\
\hline $\mathrm{d}(\mathrm{CcCCC})$ & - & {$\left[\mathrm{w}_{4} / \mathrm{d}_{4}-\mathrm{C}\right]^{+} ;\left[\mathrm{y}_{4} / \mathrm{b}_{4}-\mathrm{C}\right]^{+} ;\left[\mathrm{z}_{4} / \mathrm{a}_{4}-\mathrm{C}\right]^{+}$} & \\
\hline $\mathrm{d}(\mathrm{CTCTC})$ & {$[\mathrm{M}-\mathrm{C}+2 \mathrm{H}]^{+} ; ;[\mathrm{M}-\mathrm{C}+\mathrm{H}]^{+}$} & {$\left[\mathrm{w}_{4} / \mathrm{d}_{4}-\mathrm{C}\right]^{+} ;\left[\mathrm{x}_{4} / \mathrm{c}_{4}-\mathrm{C}\right]^{+} ;\left[\mathrm{z}_{4} / \mathrm{a}_{4}-\mathrm{C}\right]^{+} ;\left[\mathrm{z}_{3} / \mathrm{a}_{3}-\mathrm{C}\right]^{+}$} & {$[\mathrm{M}-2 \mathrm{C}+\mathrm{H}]^{+}$} \\
\hline $\mathrm{d}(\mathrm{TCCCT})$ & {$[\mathrm{M}-2 \mathrm{C}+\mathrm{H}]^{+}$} & {$\left[\mathrm{w}_{3} / \mathrm{d}_{3}-\mathrm{C}\right]^{+} ;\left[\mathrm{x}_{3} / \mathrm{c}_{3}-\mathrm{C}\right]^{+} ;\left[\mathrm{z}_{4} / \mathrm{a}_{4}-\mathrm{C}\right]^{+}$} & $\begin{array}{l}{[\mathrm{M}-\mathrm{C}+\mathrm{H}]^{+} ;\left[\mathrm{w}_{4} / \mathrm{d}_{4}-\mathrm{C}\right]^{+} ;} \\
\quad\left[\mathrm{x}_{4} / \mathrm{c}_{4}-\mathrm{C}\right]^{+}\end{array}$ \\
\hline $\mathrm{d}(\mathrm{CTTTC})$ & {$[\mathrm{M}-\mathrm{C}+\mathrm{H}]^{+}$} & {$\left[\mathrm{x}_{4} / \mathrm{c}_{4}-\mathrm{C}\right]^{+} ;\left[\mathrm{z}_{4} / \mathrm{a}_{4}-\mathrm{C}\right]^{+}$} & {$[\mathrm{M}-2 \mathrm{C}+\mathrm{H}]^{+}$} \\
\hline $\mathrm{d}(\mathrm{CCCCT})$ & {$[\mathrm{M}-\mathrm{C}+\mathrm{H}]^{+} ;[\mathrm{M}-2 \mathrm{C}+\mathrm{H}]^{+}$} & {$\left[\mathrm{w}_{4}-\mathrm{C}\right]^{+} ;\left[\mathrm{w}_{3}-\mathrm{C}\right]^{+} ;\left[\mathrm{y}_{4}-\mathrm{C}\right]^{+}$} & {$\left[d_{4}-C\right]^{+}$} \\
\hline $\mathrm{d}(\mathrm{TCCCC})$ & {$[\mathrm{M}-\mathrm{C}+\mathrm{H}]^{+} ;[\mathrm{M}-2 \mathrm{C}+\mathrm{H}]^{+}$} & {$\left[\mathrm{d}_{4}-\mathrm{C}\right]^{+} ;\left[\mathrm{b}_{4}-\mathrm{C}\right]^{+} ;\left[\mathrm{a}_{4}-\mathrm{C}\right]^{+} ;\left[\mathrm{x}_{2}-\mathrm{C}\right]^{+}$} & {$\left[w_{4}-C\right]^{+}$} \\
\hline
\end{tabular}




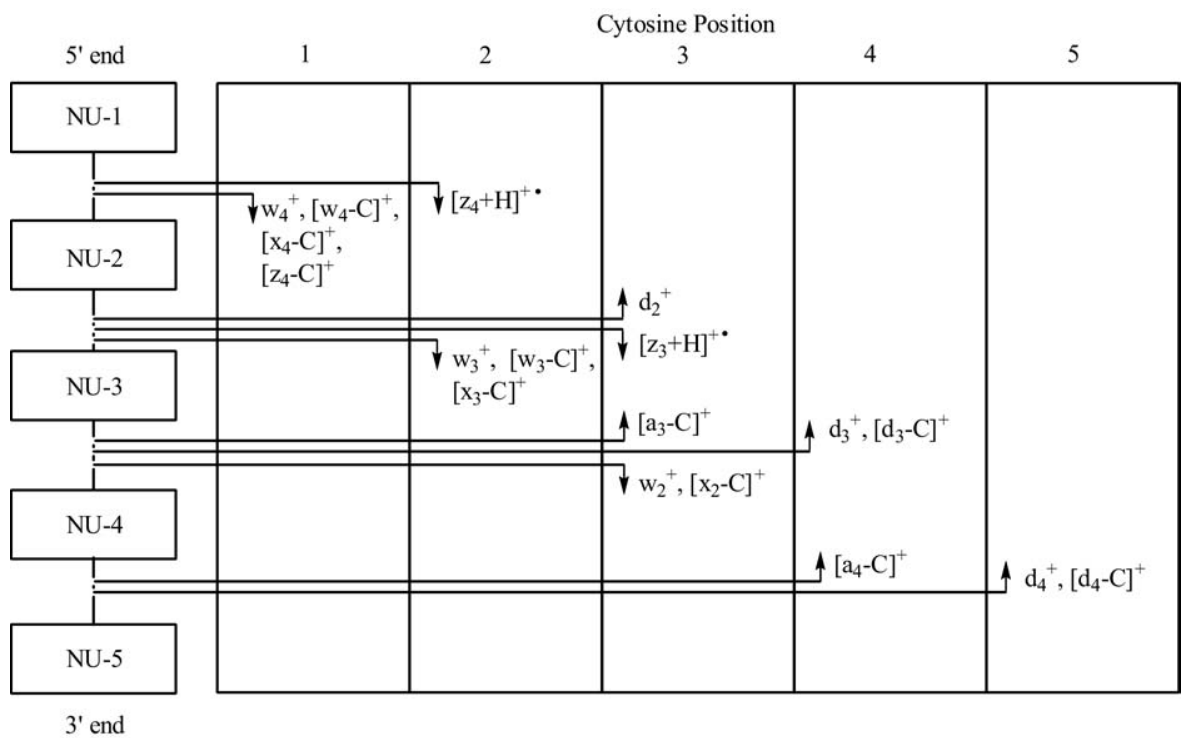

Scheme 3. A simplified correlation of the position of the cytosine with the backbone cleavage and base-loss information obtained from ECD tandem mass spectrometry analysis of various C/T binary base oligonucleotides.

the formation of $\left[\mathrm{z}_{3}+\mathrm{H}\right]^{+}$. should be associated with the cytosine at position 3 . Scheme 3 summarizes the simplified correlation. Briefly, the formation of $\mathrm{w}_{n}^{+}$ fragment was associated with the presence of cytosine at the $5^{\prime}$ side of the cleavage; whereas the formation of $\mathrm{d}_{n}^{+}$and $\left[\mathrm{z}_{n}+\mathrm{H}\right]^{+}$. fragment was associated with the presence of cytosine at the 3 'side of the cleavage. In addition, the formation of cytosine nucleoside-like fragment ions was also correlated well with the presence of cytosine at the internal nucleotides; i.e., at least at either position 2, 3, or 4 .

Similarly, strong correlation exists between the cytosine position and the occurrence of specific base-loss fragments (Table 5b). Cytosine at position 1 seems to correlate with the formation of $\left[\mathrm{w}_{4}-\mathrm{C}\right]^{+}$and $\left[\mathrm{x}_{4}-\mathrm{C}\right]^{+}$; cytosine at position 2 correlates with $\left[\mathrm{w}_{3}-\mathrm{C}\right]^{+}$and $\left[\mathrm{x}_{3}-\mathrm{C}\right]^{+}$; cytosine at position 4 correlates with $\left[\mathrm{d}_{3}-\mathrm{C}\right]^{+}$; and cytosine at position 5 correlates with $\left[\mathrm{d}_{4}-\mathrm{C}\right]^{+}$. Based on these unambiguous correlations, the formation of $\left[\mathrm{x}_{2}-\mathrm{C}\right]^{+}$in $\mathrm{d}(\mathrm{TCCCC})$ should then be correlated with the cytosine at position 3 . Some correlation ambiguities could also be found in Table $5 \mathrm{~b}$. For instance, $\left[\mathrm{z}_{4} / \mathrm{a}_{4}-\mathrm{C}\right]^{+}$ species could be observed in the ECD spectra of both $\mathrm{d}$ (CTCTC), $\mathrm{d}($ TCCCT) and $\mathrm{d}($ CTTTC); $\mathrm{d}$ (CTCTC) gave both $\left[\mathrm{z}_{4} / \mathrm{a}_{4}-\mathrm{C}\right]^{+}$and $\left[\mathrm{z}_{3} / \mathrm{a}_{3}-\mathrm{C}\right]^{+}$species; and only $\left[\mathrm{a}_{4}{ }^{-}\right.$ $\mathrm{Cl}^{+}$was found in the ECD spectrum of $\mathrm{d}$ (TCCCC). To satisfactorily explain these observations, it was postulated that both $\left[\mathrm{z}_{n}-\mathrm{C}\right]^{+}$and $\left[\mathrm{a}_{n}-\mathrm{C}\right]^{+}$species can be formed in the ECD of oligonucleotide ions; and their formation have different correlation relationships with respect to the cytosine position. Based on these postulations, $\left[\mathrm{z}_{4}-\mathrm{C}\right]^{+}$species is correlated with the cytosine at position 1 ; whereas $\left[\mathrm{a}_{3}-\mathrm{C}\right]^{+}$and $\left[\mathrm{a}_{4}-\mathrm{C}\right]^{+}$species are correlated with the cytosine at position 3 and 4 , respectively. These correlation information were also summa- rized in Scheme 3. Briefly, the formation of $\left[\mathrm{a}_{n}-\mathrm{C}\right]^{+}$, $\left[\mathrm{w}_{n}-\mathrm{C}\right]^{+},\left[\mathrm{x}_{n}-\mathrm{C}\right]^{+}$, and $\left[\mathrm{z}_{n}-\mathrm{C}\right]^{+}$species were associated with the presence of cytosine at the $5^{\prime}$ side of the cleavage; whereas the formation of $\left[\mathrm{d}_{n}-\mathrm{C}\right]^{+}$fragment was associated with the presence of cytosine at the $3^{\prime}$ side of cleavage. For the $\left[\mathrm{y}_{4}-\mathrm{C}\right]^{+}$and $\left[\mathrm{b}_{4}-\mathrm{C}\right]^{+}$species (as observed in the spectra of $\mathrm{d}(\mathrm{CCCCT})$ and $\mathrm{d}$ (TCCCC), respectively), not enough spectral information could be used to derive their correlation with the cytosine position. In addition, the formation of $[\mathrm{M}-\mathrm{C}+\mathrm{H}]^{+}$was correlated well with the presence of cytosine at either position 1 or 5 ; and the formation of $[\mathrm{M}-2 \mathrm{C}+\mathrm{H}]^{+}$was correlated with the presence of consecutive internal cytosine units, i.e., at positions 2,3 , and 4 .

On the basis of the observed correlations, it is concluded that electron capture dissociation of doublyprotonated oligonucleotides are cytosine- (or charge-) directed. From the available information, several possible mechanisms are proposed to account for the formation of some prominent fragment ions. Scheme 4 (upper) shows a sequential dissociation of the precursor ions upon capturing of an electron leading to the formation of $[\mathrm{M}+2 \mathrm{H}-\mathrm{C}]^{+}, \mathrm{w}_{n}^{+}$, and $\left[\mathrm{a}_{n}-\mathrm{C}\right]^{+}$ fragments. In this scheme, attachment of an electron neutralizes a protonated cytosine to generate a radical intermediate. Through the rearrangement of the electron density, a neutral cytosine moiety is eliminated with the concomitance formation of $[\mathrm{M}+2 \mathrm{H}-\mathrm{C}]^{+}$. The radical at the $\mathrm{C}-1$ of the sugar ring can initiate the formation of double-bond between $\mathrm{C}-1$ and $\mathrm{C}-2$ with an elimination of a hydrogen radical from $\mathrm{C}-2$ to form $\left[\mathrm{M}+\mathrm{H}-\mathrm{C}^{+}\right.$. Alternatively, the hydrogen radical may interact with the phosphate group and cleave the $\mathrm{C}-\mathrm{O}$ linkage to generate $\mathrm{w}_{n}$-fragment. The radical located at the $\mathrm{C}-3$ position can further initiate the formation of 


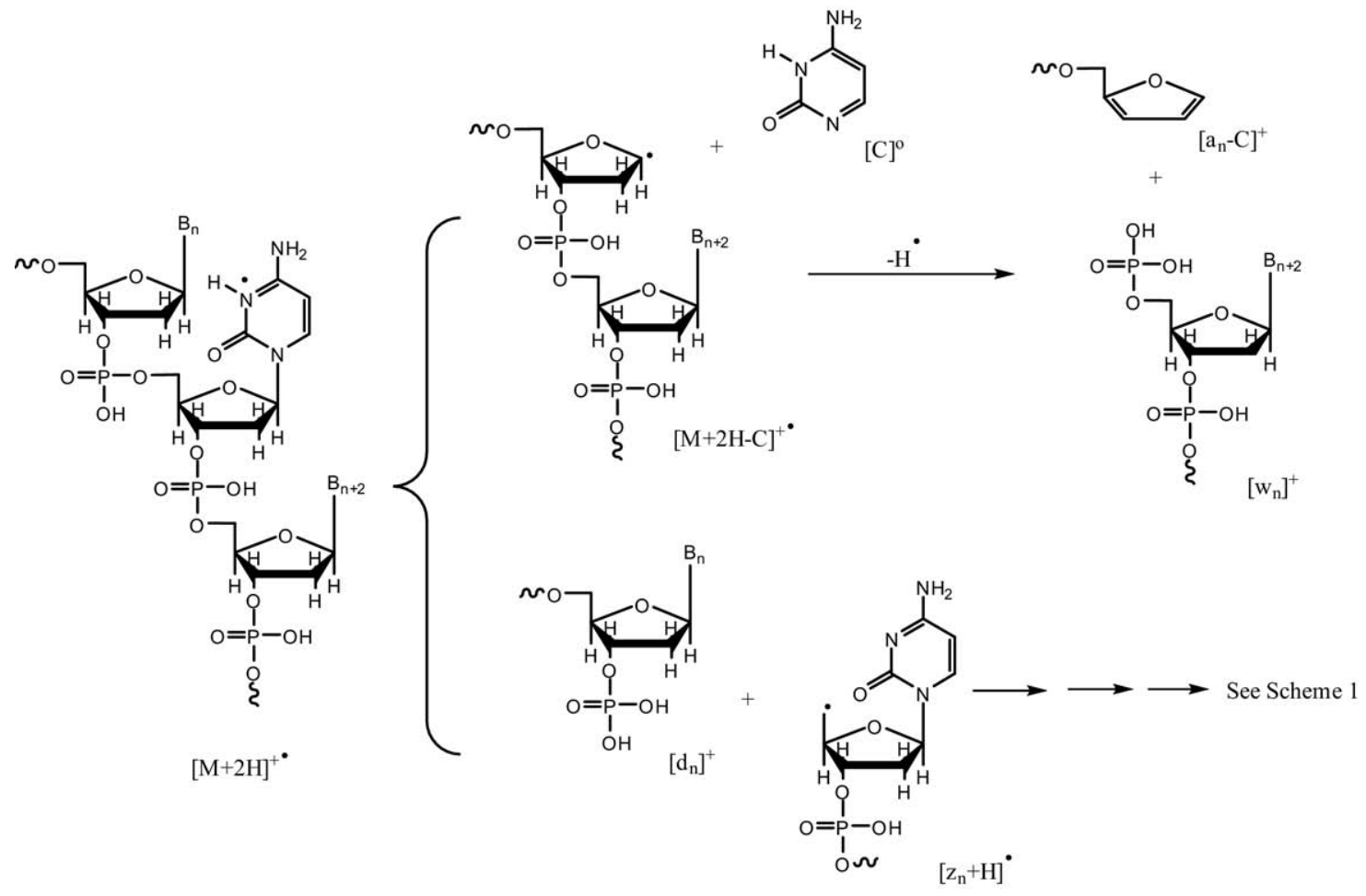

Scheme 4. Proposed mechanisms for the decomposition of the reduced doubly-protonated oligonucleotide.

double-bond between $\mathrm{C}-3$ and $\mathrm{C}-4$ with an elimination of a hydrogen radical from $\mathrm{C}-4$ to form $\left[\mathrm{a}_{n}-\mathrm{C}\right]$ fragment. It is important to note that the proposed mechanism does satisfy the correlation requirements, i.e., the presence of a cytosine nucleobase at the $5^{\prime}$-side of the backbone cleavage is essential for the formation of $\mathrm{w}_{n}$ and $\left[\mathrm{a}_{n}-\mathrm{C}\right]$ fragments.

Scheme 4 (lower) shows the formation of $\mathrm{d}_{n}^{+}, \mathrm{z}_{n}^{+}$, and nucleoside-like fragments ion from the ECD of doublycharged model oligonucleotides. Apart from eliminating the neutralized nucleobase, the reduced cytosine can also transfer a hydrogen atom to the phosphodiester leading to the cleavage of $\mathrm{O}-\mathrm{C}$ linkage and the formation of $\mathrm{d}_{n}$ and $\mathrm{z}_{n}$ ' fragment. Having a radical at the primary carbon, $z_{n}$ readily undergoes the formation of double-bond at $\mathrm{C} 4$ and $\mathrm{C} 5$. The hydrogen atom at $\mathrm{C} 4$ will migrate to nearby oxygen of the phosphodiester bridge and cleave the $\mathrm{C}-\mathrm{O}$ linkage. Another doublebond will be formed across $\mathrm{C} 3$ and $\mathrm{C} 2$ and the hydrogen atom at $\mathrm{C} 2$ will interact with the $\mathrm{P}=\mathrm{O}$ and initiate the cleavage of $\mathrm{O}-\mathrm{C}$ linkage. In summary, $\mathrm{z}_{n}$ will undergo secondary dissociation to form nucleoside-like fragment, phosphoric acid $\left(\mathrm{H}_{3} \mathrm{PO}_{4}\right)$ and $\mathrm{z}_{(n-1)}$. The proposed mechanism has two important features: (1) the formation of $\mathrm{d}_{n}$ and $\mathrm{z}_{n}$ fragment ions are associated with a protonated nucleobase at the $3^{\prime}$-position of the backbone cleavage site; and (2) $z_{n}{ }^{\prime}$ can undergo secondary dissociation to form smaller $\mathrm{z}$, e.g., $\mathrm{z}_{(\mathrm{n}-1)}$, and nucleoside-like fragments.

For $\left[\mathrm{w}_{n}-\mathrm{C}\right]$ and $\left[\mathrm{d}_{n}-\mathrm{C}\right]$ fragments, it is conceivable that these fragment ions were formed from the secondary dissociation of the $\mathrm{w}_{n}$ and $\mathrm{d}_{n}$ fragments. This is consistent with the fact that $\left[\mathrm{w}_{n}-\mathrm{C}\right]$ and $\left[\mathrm{d}_{n}-\mathrm{C}\right]$ fragments have the same correlation relationship with respect to the cytosine position as compared to their precursor species, i.e., $\mathrm{w}_{n}$ and $\mathrm{d}_{n}$, respectively. When an electron is captured by the protonated nucleobase, ion-electron recombination at the nucleobase initiates the backbone cleavage to produce fragment ions. If the internal energy of those fragment ions remains high, the remaining energy will randomize within the fragment ion and will have finite possibility of undergoing a base loss reaction. In the CID of oligonucleotides [8b, 35, 41], base loss from those protonated fragment ions can occur via two different possible pathways $\left(E_{1}\right.$ and $E_{2}$ mechanisms). Similarly, $\mathrm{w}_{n}^{+}$and $\mathrm{d}_{n}^{+}$fragments might also undergo $E_{1}$ or $E_{2}$ reactions to form the [wn - C]+ and $[\mathrm{dn}-\mathrm{C}]+$ fragment ions.

For $\left[z_{n}-C\right]$ fragments, the situation becomes more complicated. These fragments have different correlation relationship with the cytosine position in comparison with $z_{n}$. The formation of $z_{n}{ }^{\cdot}$ was found to correlate well with the presence of cytosine at the $3^{\prime}$-position of the broken phosphodiester linkage; whereas $\left[z_{n}-C\right]$ fragments were correlated with the cytosine at $5^{\prime}$ position of the broken phosphodiester linkage. This implies that $\left[z_{n}-C\right]$ fragments are not secondary dissociation products of $\mathrm{z}_{n}$. Another intriguing observation is related to the formation of $\left[z_{4}-C\right]$ fragments in the ECD spectra of $d$ (CTTTC) and $d$ (CTCTC). The 
cytosine nucleobase at the 5'-end of the oligonucleotides is required for the backbone cleavage and a remote cytosine nucleobase has to be eliminated during the backbone cleavage process. With the limited experimental information, the mechanism for the formation of $\left[\mathrm{z}_{n}-\mathrm{C}\right]$ in our model systems remains obscure.

\section{Conclusions}

By cross comparing the fragmentation pattern of several model oligonucleotides under ECD conditions, interesting spectral features that are related to the mechanisms of dissociation were extracted. The formation of many prominent sequence ions was found to be sensitive to the position of the cytosine (or the position of the charge carrier). In summary, the occurrence of $\mathrm{w}_{n},\left[\mathrm{w}_{\mathrm{n}}-\mathrm{C}\right],\left[\mathrm{a}_{\mathrm{n}}-\mathrm{C}\right],\left[\mathrm{x}_{\mathrm{n}}-\mathrm{C}\right],\left[\mathrm{z}_{\mathrm{n}}-\mathrm{C}\right]$ sequence ions was well-correlated with the presence of a cytosine nucleobase at the $5^{\prime}$-side of the broken phosphodiester linkage; whereas the occurrence of $\mathrm{d}_{n},\left[\mathrm{~d}_{n}-\mathrm{C}\right]$ and $\mathrm{z}_{n}$ sequence ions was correlated with the presence of a cytosine nucleobase at the 3 '-side of the broken phosphodiester linkage. Based on our experimental findings, it is believed that the fragmentation reactions of protonated oligonucleotides are charged-directed with the electron being captured by the protonated nucleobase. Several feasible mechanisms of dissociation were tentatively proposed to account for the observed fragmentation pattern.

\section{Acknowledgments}

The authors acknowledge support for this work by a grant (no. CUHK 2160273) from the Research Grants Council of the Hong Kong Special Administrative Region, China.

\section{References}

1. Nickerson, D. A.; Tobe, V. O.; Taylor, S. L. PolyPhred: Automating the Detection and Genotyping of Single Nucleotide Substitutions using Fluorescence-Base Resequencing. Nucleic Acids Res. 1997, 25, 2745-2751.

2. Karas, M.; Bachmann, D.; Bahr, U.; Hillenkamp, F. Matrix-Assisted Ultraviolet Laser Desorption of Non-Volatile Compounds. Int. J. Mass Spectrom. Ion Process 1987, 78, 53-68.

3. Karas, M.; Hillenkamp, F. Laser Desorption Ionization of Proteins with Molecular Masses Exceeding 10,000 Daltons. Anal. Chem. 1988, 60, 2299-2301.

4. Fenn, J. B.; Mann, M.; Meng, C. K.; Wong, S. F.; Whitehouse, C. M. Electrospray Ionization for Mass Spectrometry of Large Biomolecules. Science 1989, 246, 64-71.

5. Mann, M.; Shen, S.; Fenn, J. B. Electrospray Mass Spectrometry. NATO ASI Series, C: Math. Phys. Sci. 1992, 353, 145-163.

6. Hofstadler, S. A.; Sannes-Lowery, K. A.; Hannis, J. C. Analysis of Nucleic Acids by FTICR MS. Mass Spectrom. Rev. 2005, 24, 265-285.

7. (a) Gauthier, J. W.; Trautman, T. R.; Jacobson, D. B. Sustained OffResonance Irradiation for Collision-activated Dissociation involving Fourier Transform Mass Spectrometry. Collision-activated Dissociation Technique that Emulates Infrared Multiphoton Dissociation. Anal. Chim. Acta 1991, 246, 211-225; (b) Biemann, K. Sequencing of Peptides by Tandem Mass Spectrometry and High-Energy Collision-Induced Dissociation. Methods Enzymol. 1990, 193, 455-479.

8. (a) Wang, P. P.; Barlett, M. G.; Martin, L. B. Electrospray CollisionInduced Dissociation Mass Spectra of Positively Charged Oligonucleotides. Rapid Commun. Mass Spectrom. 1997, 11, 846-856; (b) Weimann, A.; Iannitti-Tito, P.; Sheil, M. M. Characterization of Products Ions in High-Energy Tandem Mass Spectra of Protonated Oligonucleotides Formed by Electrospray Ionization. Int. J. Mass Spectrom. 2000, 194, 269-288; (c) Wang, Z.; Wan, K. X.; Ramanathan, R.; Taylor, J. S.; Gross, M. L. Structure and Fragmentation Mechanisms of Isomeric T-Rich Oligodeoxynucleotides: A Comparison of Four Tandem Mass Spectrometric Methods. J. Am. Soc. Mass Spectrom. 1998, 9, 683-691.
9. Mabud, M. A.; Dekrey, M. J.; Cooks, R. G. Surface-Induced Dissociation of Molecular Ions. Int. I. Mass Spectrom. Ion Processes 1985, 67, 285-294.

10. (a) Flora, J.W.; Muddiman, D. C. Selective, Sensitive, and Rapid Phosphopeptide Identification in Enzymatic Digests Using ESI-FTICR-MS with Infrared Multiphoton Dissociation. Anal. Chem. 2001, 73, 3305-3311; (b) Little, P. D.; Speir, J. P.; Senlo. M. W.; O'Conner, P. B.; McLafferty, F. W. Infrared Multiphoton Dissociation of Large Multiply Charged Ions for Biomolecule Sequencing. Anal. Chem. 1994, 66, 2809-2815.

11. Price, W. D.; Schnier, P. D.; Williams, E. R. Tandem Mass Spectrometry of Large Biomolecule Ions by Blackbody Infrared Radiative Dissociation. Anal. Chem. 1996, 68, 859-866.

12. (a) Gu, C.; Tsaprailis, G.; Breci, L.; Wysocki, V. H. Selective Gas-Phase Cleavage at the Peptide Bond C-Terminal to Aspartic Acid in FixedCharge Derivatives of Asp-Containing Peptides. Anal. Chem. 2000, 72, 5804-5813; (b) Catinella, S.; Pelizzi, N.; Barboso, S.; Favretto, D.; Seraglia, R.; Traldi, P. On the Detailed Mechanisms of Collision-Induced Dissociation Experiments Performed by Electrospray Ion Trap. Rapid Commun. Mass Spectrom. 2002, 16, 1897-1902.

13. Zubarev, R. A.; Kelleher, N. L.; McLafferty, F. W. Electron Capture Dissociation of Multi-Charged Protein Cations. A Nonergodic Process. J. Am. Chem. Soc. 1998, 120, 3265-3266.

14. Shi, S. D.-H.; Hemling, M. E.; Carr, S. A.; Horn, D. M.; Lindh, I. McLafferty, F. W. Phosphopeptide/Phosphoprotein Mapping by Electron Capture Dissociation Mass Spectrometry. Anal. Chem. 2001, 73, $19-22$.

15. Mirgorodskya, E.; Roepstoff, P. Zubarev, R. A. Localization of OGlycosylation Sites in Peptides by Electron Capture Dissociation in a Fourier Transform Mass Spectrometer. Anal. Chem. 1999, 71, 4431-4436.

16. Kelleher, N. L.; Zubarev, R. A.; Bush, K.; Furie, B.; Furie, B. C. McLafferty, F. W.; Walsh, C. T. Localization of Labile Posttranslational Modifications by Electron Capture Dissociation Mass Spectrometry. Anal. Chem. 2001, 73, 19-22.

17. Håkansson, K.; Cooper, H. J.; Emmett, M. R.; Costello, C. E.; Marshall, A. G.; Nilsson, C. L. Electron Capture Dissociation and Infrared Multiphoton Dissociation MS/MS of an N-Glycosylated Tryptic Peptide to Yield Complementary Sequence Information. Anal. Chem. 2001, $73,4530-4536$

18. Ziqiang, G.; Yates, N. A.; Bakhtiar, R. Detection and Characterization of Methionine Oxidation in Peptides by Collision-Induced Dissociation and Electron Capture Dissociation. J. Am. Soc. Mass Spectrom. 2003, 14, 605-613.

19. Horn, D. M.; Zubarev, R. A.; McLafferty, F. W. Automated De Novo Sequencing of Proteins by Tandem High-Resolution Mass Spectrometry. PNAS 2000, 97, 10313-10317.

20. Zubarev, R. A.; Horn, D. M.; Fridriksson, E. K.; Kelleher, N. L.; Kruger N. A.; Lewis, M.A.; Carpenter, B. K.; McLafferty, F. W. Electron Capture Dissociation for Structural Characterization of Multiply Charged Protein Cations. Anal. Chem. 2000, 72, 563-573.

21. Nielsenm, M. L.; Budnik, B. A.; Haselmann, K. F.; Olsen, J. V.; Zubarev, R. A. Intramolecular Hydrogen Atom Transfer in Hydrogen-Deficient Polypeptide Radical Cations. Chem. Phys. Lett. 2000, 330, 558-562.

22. Horn, D. M.; Ge, Y.; McLafferty, F. W. Activated Ion Electron Capture Dissociation for Mass Spectral Sequencing of Larger (42 kDa) Proteins. Anal. Chem. 2000, 72, 4778-4784.

23. Zubarev, R. A.; Haselmann, K. F.; Budnik, B.; Kjeldsen, F.; Jensen, F. Towards an Understanding of the Mechanism of Electron-Capture Dissociation: A Historical Perspective and Modern Ideas. Eur. J. Mass Spectrom. 2002, 8, 337-349.

24. Syrstad, E. A.; Turecek, F. Toward a General Mechanism of Electron Capture Dissociation. J. Am. Soc. Mass Spectrom. 2005, 16, 208-224.

25. (a) Håkansson, H.; Hudgins, R. R.; Marshall, A. G.; O'Hair, R. A. J. Electron Capture Dissociation and Infrared Multiphoton Dissociation of Oligodeoxynucleotide Dications. J. Am. Soc. Mass Spectrom. 2003, 14, 23-41; (b) Schultz, K. N.; Håkansson, K. Rapid Electron Capture Dissociation of Mass-Selectively Accumulated Oligodeoxynucleotide Dications. Int. J. Mass Spectrom. 2004, 234, 123-130.

26. Yang, J.; Hakansson, K. Fragmentation of Oligoribonucleotides from Gas-Phase Ion-Electron Reactions. J. Am. Soc. Mass Spectrom. 2006, 17, $1369-1375$.

27. (a) Wan, K. X.; Gross, J.; Hillenkamp, F.; Gross, M. L. Fragmentation Mechanisms of Oligodeoxynucleotides Studied by H/D Exchange and Electrospray Ionization Tandem Mass Spectrometry. J. Am. Soc. Mass Spectrom. 2001, 12, 193-205. (b) Chan, T.-W. D., Fung, Y. M. E.; Li, Y. C. L. A Study of Fast and Metastable Dissociations of AdenineThymine Binary-Base Oligonucleotides by Using Positive-Ion MALDITOF Mass Spectrometry. I. Am. Soc. Mass Spectrom. 2002, 13, 1052-1064.

28. Fong, W. Y.; Chan, T.-W. D. A Novel Non-Metallized Tip for Electrospray Mass Spectrometry at Nanoliter Flow Rate. J. Am. Soc. Mass Spectrom. 1999, 10, 72-75.

29. Caravatti, P.; Allemann, M. The 'Infinity Cell': A New Trapped-Ion Cell with Radiofrequency Covered Trapping Electrodes for Fourier Transform Ion Cyclotron Resonance Mass Spectrometry. Org. Mass Spectrom. 1991, 26, 514-518.

30. Chan, T.-W. D.; Ip, W. H. H. Optimization of Experimental Parameters for Electron Capture Dissociation of Peptides in a Fourier Transform Mass Spectrometer. J. Am. Chem. Soc. Mass Spectrom. 2002, 13, 1396-1406.

31. Frisch, M. J.; Trucks, G. W.; Schlegel, H. B.; Scuseria, G. E.; Robb, M. A.; Cheeseman, J. R.; Montgomery, J. A.; Jr. Vreven, T.; Kudin, K. N.; Burant, J. C.; Millam, J. M.; Iyengar, S. S.; Tomasi, J.; Barone, V.; Mennucci, B.; Cossi, M.; Scalmani, G.; Rega, N.; Petersson, G. A.; Nakatsuji, H.; Hada, 
M.; Ehara, M.; Toyota, K.; Fukuda, R.; Hasegawa, J.; Ishida, M.; Nakajima, T.; Honda, Y.; Kitao, O.; Nakai, H.; Klene, M.; Li, X.; Knox, J. E.; Hratchian, H. P.; Cross, J. B.; Adamo, C.; Jaramillo, J.; Gomperts, R.; Stratmann, R. E.; Yazyev, O.; Austin, A. J.; Cammi, R.; Pomelli, C.; Ochterski, J. W.; Ayala, P. Y.; Morokuma, K.; Voth, G. A.; Salvador, P.; Dannenberg, J. J.; Zakrzewski, V. G.; Dapprich, S.; Daniels, A. D.; Strain, M. C.; Farkas, O.; Malick, D. K.; Rabuck, A. D.; Raghavachari, K.; Foresman, J. B.; Ortiz, J. V.; Cui, Q.; Baboul, A. G.; Clifford, S.; Cioslowski, J.; Stefanov, B. B.; Liu, G.; Liashenko, A.; Piskorz, P.; Komaromi, I.; Martin, R. L.; Fox, D. J.; Keith, T.; Al-Laham, M. A.; Peng, C. Y.; Nanayakkara, A.; Challacombe, M.; Gill, P. M. W.; Johnson, B.; Chen, W.; Wong, M. W.; Gonzalez, C.; Pople, J. A. Gaussian 03, Revision B.04, Gaussian, Inc., Pittsburgh PA, 2003

32. Becke, A. D. A New Mixing of Hartree-Fock and Local DensityFunctional Theories. J. Chem. Phys. 1993, 98, 1372-1377.

33. Becke, A. D. Density-Functional Thermochemistry. III. The Role of Exact Exchange. J. Chem. Phys. 1993, 98, 5648-5652.

34. Stephens, P. J.; Delvin, F. J.; Cabalowski, C. F.; Fisch, M. J. Ab Initio Calculation of Vibrational Absorption and Circular Dichroism Spectra Using Density Functional Force Fields. J. Phys. Chem. 1994, 98, 1162311627

35. Ni, J.; Matthews, M. M. A.; McCloskey, J. A. Collision-Induced Dissociation of Polyprotonated Oligonucleotides Produced by Electrospray Ionization. Rapid Commun. Mass Spectrom. 1997, 11, 535-540.
36. Kjeldsen, F.; Zubarev, R. A. Secondary Losses via $\gamma$-Lactam Formation in Hot Electron Capture Dissociation: A Missing Link to Complete De Novo Sequencing of Proteins? J. Am. Chem. Soc. 2003, $125,6628-6629$.

37. Mirgorodskya, E.; Roepstoff, P.; Zubarev, R. A. Localization of O-Glycosylation Sites in Peptides by Electron Capture Dissociation in a Fourier Transform Mass Spectrometer. Anal. Chem. 1999, 71, 4431-4436.

38. Gross, J.; Leisner, A.; Hillenkamp, F.; Hahner, S.; Karas, M.; Lutzenkirchen S. F.; Nordhoff, E. Investigations of the Metastable Decay of DNA under Ultraviolet Matrix-Assisted Laser Desorption/Ionization Conditions with Post-Source-Decay Analysis and Hydrogen/Deuterium Exchange. J. Am. Soc. Mass Spectrom. 1998, 9, 866-878.

39. Podolyan, T. Y.; Gorb, L.; Leszczynski, J. Protonation of Nucleic Acid Bases. A Comprehensive Post-Hartree-Fock Study of the Energetics and Proton Affinities. J. Phys. Chem. A 2000, 104, 7346-7352.

40. Smets, J.; Houben, L.; Schoone, K.; Maes, G. Adamowicz. L. Multiple Site Proton Affinities of Methylated Nucleic Acid Bases. Chem. Phys. Lett. 1996, 262, 789-796.

41. Vrkic, A. K.; O'Hair, R. A. J.; Foote, S. Reid, G. E. Fragmentation Reactions of all 64 Protonated Trimer Oligodeoxynucleotides and 16 Mixed Base Tetramer Oligodeoxynucleotides via Tandem Mass Spectrometry in an Ion Trap. Int. J. Mass Spectrom. 2000, 194, 145-164. 